\title{
Music, Silence, and the Senses in a Late Fifteenth-Century Book of Hours
}

\author{
TIM SHEPHARD, LAURA ȘTEFĂNESCU, AND SERENELLA SESSINI, \\ University of Sheffield
}

\begin{abstract}
Although it is common in the musicological literature to compare decorated music books with books of hours, studies addressing the musical features of books of hours are rare. This article considers musical features in the decoration of a book of hours made by leading illuminators in Ferrara ca. 1469. Images appearing in books of hours are considered to have had an exemplary and meditative function in relation to devotional practice; therefore, this study asks what the reader was intended to learn from musical images, drawing conclusions about the alignment of the senses and the significance of music in fifteenth-century religious experience.
\end{abstract}

\section{INTRODUCTION}

IT HAS BECOME something of a commonplace in the musicological literature to draw comparisons between books of hours and manuscripts containing polyphonic music. Bonnie Blackburn, for example, has pointed out that the elite owners and users of the magnificent manuscripts produced in the Habsburg-Burgundian Alamire scriptorium must have registered the close similarity of their Ghent-Bruges style decoration to the illuminations gracing their much smaller books of hours, such that their treasured music books "must have seemed like a musical book of hours." ${ }^{1}$ Responding to Blackburn's comment, Honey Meconi has discussed chansonniers as "secular equivalents of books of hours," in terms of their size, decoration, intent to guide and instruct, and in some respects in terms of their contents. ${ }^{2}$ Cultivating the same link in broader terms, Jane Alden has linked the Loire Valley chansonniers and books of hours decorated in the style of Jean Fouquet (1420-81) as complementary products of a "culture of small

This research was conducted within the three-year project "Music in the Art of Renaissance Italy, ca. 1420-1540," funded by a Leverhulme Trust Research Project Grant. The authors are grateful to Bonnie Blackburn, Laurie Stras, and our project advisor Beth Williamson for kindly offering stimulating comments and suggestions on an earlier draft of this article.

${ }^{1}$ Blackburn, 2003, 161-62.

${ }^{2}$ Meconi, 653-54.

Renaissance Quarterly 70 (2017): 474-512 (c) 2017 Renaissance Society of America. 
books," their similar decorations intended to reflect positively on the identity of their owners. ${ }^{3}$

Given the apparently widespread recognition of a relationship of some kind between books of hours and books of music, it is perhaps somewhat surprising that detailed studies considering the role of music in, or the musical role of, books of hours are few and far between. Two studies have addressed the texts found in books of hours by placing them in relation to music. In a brief essay on a book of hours made in Florence for Pope Leo X (r. 1513-21), John Constant has drawn attention to a hymn text also set as a motet by Josquin des Prez (ca. 1450-1521), noting the variances between the two texts. ${ }^{4}$ Much more substantial and significant is the study of Giacomo Baroffio, in which the variations among individual liturgical texts transmitted in multiple books of hours are studied as documents of local and regional practices. ${ }^{5}$ Baroffio extends this approach to the chant melodies transmitted in the relatively small group of books of hours in which texts are presented with music notation, arguing that for the many clerical owners of books of hours musical performance of the liturgical texts therein (whether presented with notation or not) must have been an obvious and natural strategy of personal prayer. ${ }^{6}$

Among studies treating the decoration of books of hours, most thorough is Margareth Boyer Owens's 1987 doctoral dissertation, in which the author reviews in systematic fashion musical subjects in the decoration of the more than 300 books of hours held by the Walters Art Museum in Baltimore. ${ }^{7}$ More recently, Björn Tammen has briefly discussed musical subjects in the books of hours held by the Austrian National Library in Vienna, giving particular attention to the musical elements in the marginal decorations, which he interprets along the lines suggested by the studies on marginalia published by Michael Camille and Lucy F. Sandler. ${ }^{8}$ Owens's and Tammen's studies are concerned above all with the musical iconography found in the sources they address, drawing together examples from a large corpus of manuscripts produced and used in the main in France and Flanders. The present study asks a different question, set in a different milieu: what might the representation of music in books of hours tell us about devotional practice, and about music, among the elites of fifteenth-century Italy? Our investigation also proceeds in a different manner, viz., through the detailed analysis of musical elements in the decorations of a single book of hours, the date and location of whose creation can be pinpointed exactly.

\author{
${ }^{3}$ Alden, $168-75$. \\ ${ }^{4}$ Constant, 330-32. \\ ${ }^{5}$ Baroffio. \\ ${ }^{6}$ Ibid., 55-56, 63-69. \\ ${ }^{7}$ M. B. Owens. \\ ${ }^{8}$ Tammen; Camille, 1992; Sandler.
}


The J. Paul Getty Museum MS Ludwig IX 13 (hereafter Gualenghi-d'Este Hours) was created in Ferrara by Taddeo Crivelli (fl. 1451-79) and Guglielmo Giraldi (fl. 1445-89), two of the leading Italian illuminators of the second half of the fifteenth century, for Andrea Gualengo (d. 1480) and his wife Orsina d'Este (b. 1430s?). ${ }^{9}$ Andrea, a member of the local aristocracy whose family had long served the Este dukes of Ferrara, acted as adviser and senior diplomat for Duke Borso d'Este (r. 1450-71) and was rewarded for his service in 1469 with the gift of an Este bride. Andrea's coat of arms appears early in the manuscript, confirming his ownership, and Este devices appear on two later pages, confirming Orsina's; both are shown in prayer with their two children in one of the miniatures. Kurt Barstow, author of the fundamental study of this manuscript, assumes that it was created in the immediate context of the marriage- that is, ca. 1469-70. One might readily suppose it to have been a wedding gift from Borso, who died in 1471-books of hours frequently played that role. An element of confusion is thrown into the dating by the two sons appearing in the donor portrait: they are certainly not infants but presumably relate to one of Orsina's two previous husbands (both bride and groom were somewhat mature at the date of their marriage).

The role books of hours played in the private devotional practices of laypeople in the fifteenth century has been extensively discussed in the literature. ${ }^{10}$ At the heart of a book of hours was the Office of the Virgin, a set of brief, quasi-liturgical Marian prayers to be recited every day at the eight canonical hours. Among these, the owner of a book of hours could interleave the Hours of the Cross and of the Holy Spirit, the Office of the Dead, the seven penitential psalms, and prayers addressed to the Virgin and various saints. Numerous contemporary imagesincluding one in the Gualenghi-d'Este Hours, discussed below—show the pious standing or kneeling before an image of the Virgin in a domestic setting, reading from a devotional book placed on a lectern or prie-dieu, indicating the manner in which this daily observance should ideally be accomplished. ${ }^{11}$

The images appearing in books of hours are conventionally understood to be exemplary and meditative: they show the Virgin and saints in attitudes of prayer, praise, and religious contemplation, on which the reader might meditate and aspire to emulate. ${ }^{12}$ The Gualenghi-d'Este Hours includes twenty-one full-page

${ }^{9}$ The fundamental study of this manuscript is Barstow, on which the summary given in this paragraph is based.

${ }^{10}$ The literature on books of hours is of course very extensive, but the cornerstone texts include Delaissé; Harthan, esp. 11-39; Wieck, 1997 and 2001; Duffy; Reinburg; Hindman and Marrow.

${ }^{11}$ Although, of course, in practice the occasions for using such books were rather diverse: see Reinburg, 109-10.

${ }^{12}$ See, for example, ibid., 112-27. 
miniatures with associated marginal decoration, four of which feature music in some guise: three have musical notation integrated into the decorative apparatus, and the fourth depicts a musical episode in the life of a saint. Barstow has discussed all four in detail, but with only casual reference to their musical features. ${ }^{13}$ In the context of a suite of images intended to function as exemplars of pious behavior ripe for meditation and emulation, in a manuscript designed to structure the daily recitation of private prayers, what might be the significance of these musical elements? This study attempts to find some answers to this question, but before addressing the images directly it will be necessary to sketch in a broader view of the role of music in private devotional experience in Italy in ca. 1470 , locating it in relation to the better-understood role of images.

\section{IMAGE AND MUSIC IN DEVOTIONAL PRACTICE}

The role played by the sense of sight in devotional contexts in the Renaissance is already the subject of a substantial literature, but it will be worthwhile to rehearse the main points here in order to facilitate a comparison with the less familiar case of hearing that follows. ${ }^{14}$ Sight was engaged in religious experience first and foremost through the widespread, well-documented practice of using images as an aid to meditation. The understanding of vision from a religious perspective was indebted to the ideas of Saint Augustine (354-430), whose texts stocked the private libraries of fifteenth-century Italy and whose views retained huge influence. ${ }^{15}$ In his commentary on the first three chapters of Genesis, De Genesi ad litteram (The literal meaning of Genesis), he describes three levels of visual perception. The lowest is bodily vision, which is external and mediated by the eyes, functioning on an outer level. The next two represent inner levels of sight: one is spiritual vision, which is the mental representation of images in their absence, for example through memory and imagination; the third and highest is intellectual vision, through which one has access to a true understanding of what one sees. ${ }^{16}$ In the rational mind, Augustine explained, "there is a sort of eye of the soul, where the image and recognition of God is to be found." 17

${ }^{13}$ Barstow, 45-53, 134-47.

${ }^{14}$ Essential studies of the senses in the Renaissance context include Nichols, Kablitz, and Calhoun; Nelson; Jütte; Kessler; Nordenfalk; Rudy; Vinge.

${ }^{15}$ For example, the library of Borso d'Este contained a copy of Augustine's De civitate Dei. See Bertoni, 385 (item 28, "Comentum super Libro Augustinj de Civitate Dei"), 393 (item 108, "Scriptum super Augustino De Civitate Dei”).

${ }^{16}$ Augustine, 1841b, 458-79 (De Genesi ad litteram 12.6-30); in translation, Augustine, 1990, 464-99.

${ }^{17}$ Augustine, 1990, 472 (De Genesi 12.7.18); Augustine, 1841b, 460: "ubi est quidam tamquam oculus animae, ad quem pertinet imago et agnitio Dei.” 
Augustine makes a distinction between outer sight, centered on the eyes, and inner sight, which takes place in the mind, heart, or soul. The outer, anatomical sight was additionally the subject of an influential theorization within the ancient medical tradition, revived during the Renaissance: the discussion of light and color found in Aristotle's De anima (On the soul) and the anatomical scholarship of Galen (ca. 130-ca. 210). ${ }^{18}$ Drawing on these ideas, and also those of Avicenna (ca. 980-1037), the Bolognese anatomist Mondino dei Liuzzi (ca. 1270-1326) claims in his Anothomia (Anatomy, 1316) that in the middle ventricle of the brain "there is the common sense, which appropriates the images brought by the special senses; therefore these senses finish in this region, like streams [going] to the source." ${ }^{19}$ The Anothomia became a classic text and was used as a textbook in medical schools for the following three centuries, so the idea that images were perceived through the eyes and then taken to a ventricle in the brain became common currency.

The medical understanding current in fifteenth-century Italy also supported the belief that an inner sense operates on an imaginative level, functioning as a mind's eye. ${ }^{20}$ This type of vision is linked to the concept of imageless devotion, according to which devotees were able to see beyond their corporeal vision, using their inner sight to contemplate images that were not material but spiritual. ${ }^{21}$ Devotional seeing of this kind is reported with approval in the widely disseminated letters of Saint Jerome (ca. 347-420), mentioning that pilgrims to the tomb of Christ in Jerusalem had seen Christ's body in their minds, and also that Jerome's companion, Paula, saw in Bethlehem "with the eyes of faith the infant Lord wrapped in swaddling clothes and crying in the manger." 22 Similarly, in his In Johannis Evangelium tractatus (Lectures on the Gospel of Saint John), Saint Augustine envisaged Christ anticipating the solace that his disciples would take after their "carnal view" of him was erased by his death,

\footnotetext{
${ }^{18}$ Aristotle, 103-09 (De anima 2.7); Galen, 2:681-723 (De usu partium 16). The De anima enjoyed numerous Italian printed editions from the 1470s onward and the library of Borso d'Este had copies of several of Aristotle's writings, as well as a copy of one of Galen's works: Bertoni, 384 (item 18, "Aristotelis de sententijs"; item 10, "Galienus"), 392 (item 90, "Liber Secretorum Aristoteliis"; item 92, "Loycha Aristotellis").

${ }^{19}$ Mondino dei Liuzzi, n.p., chap. "De anothomia cerebri”: "In medio vero huius est sensus communis, qui est apprehendens species delatas a sensibus particularibus, et ideo sensitiva haec terminantur ad illum locum ut rivi ad fontem.”

${ }^{20}$ See Williamson, 3; Quiviger, 2003, 72-74; Quiviger, 2010, 15-19; Camille, 2000, 198-200; Vinge, 15-21.

${ }^{21}$ Williamson, 12-13.

${ }^{22}$ Jerome, 1893, 60-65 (Epistulae 46), quote on 199 (Epistulae 108.10); Jerome, 1845, 834: "cernere se oculis fidei infantem pannis involutum, vagientem in praesepi Dominum." Saint Jerome's Letters were printed in Italy, in the vernacular, in 1497: Schutte, 210. On this topic, see especially Deshman, 530-31.
} 
"because that inward sight, wherewith the Holy Spirit was yet to comfort them, was undoubtedly superior; not by bringing a human body into the bodies of those who saw, but by infusing Himself into the hearts of those who believed."23

The practical use of images in devotion rested principally on the authority and recommendation of Saint Gregory the Great (ca. 540-604). In his Homiliae in Ezechielem (Homilies on Ezekiel, 601), Saint Gregory interprets a prophecy regarding the destruction of Jerusalem, which he explains through an allegorical description of a drawing of the city: the drawing would stimulate heavenly visions of the Holy Land in those viewing it, so that they could meditate upon them. ${ }^{24}$ Similarly, in an eighth-century addition (thought genuine in the Renaissance) within a letter to Secundinus, (pseudo-)Gregory praises his correspondent because "you seek with all your heart and all intentness Him, whose picture you wish to have before your eyes, so that every day, the corporeal sight renders him visible; thus when you see the picture, you are inflamed in your soul with love for him whose image you wish to see. We do no harm in wishing to show the invisible by means of the visible." 25 This practice was adopted into the Franciscan and Dominican meditation guidebooks that circulated widely in Renaissance Italy. For example, the Meditationes Vitae Christi (Meditations on the life of Christ) attributed in the period to Saint Bonaventure (1221-74) but really a work of the fourteenth century, gives the example of Saint Cecilia, who always carried the Gospel with her. The author imagines her devotional experience: "And when she had finished the text she began again with sweet and pleasant enjoyment to ponder on these things, cultivating them in the secret of her heart with prudent consideration." ${ }^{26}$ The private use of sacred artworks was even recommended by the Dominican reformer Girolamo Savonarola (1452-98), but only if they were of minimal material value, to encourage religious meditation. ${ }^{27}$ According to Savonarola's treatise Triumphus Crucis de

\footnotetext{
${ }^{23}$ Augustine, 1873, 367 (Tractate 94.4); Augustine, 1954, 563: "quia carnalis . . . adspectus," "quia uisus interior ipse est utique melior, quo eos consolaturus fuerat Spiritus sanctus; non cernentium corporibus ingestururs corpus humanum, sed seipsum credentium pectoribus infusurus."

${ }^{24}$ "In order to draw in the mind of the listener the city of Jerusalem" ("ut describi in audientis mente ciuitas Hierusalem"): Gregory, 1986, 1:524 (Homiliae in Ezechielem 12.23).

${ }^{25}$ Kessler, 121; Gregory, 1982, 1110: "quia illum in corde tota intentione quaeris, cuius imaginem prae oculis habere desideras, ut uisio corporalis cotidiana reddat exsertum et, dum picturam uides, ad illum animo inardescas, cuius imaginem uidere desideras. Ab re non facimus, si per uisibilia inuisibilia demonstramus."

${ }^{26}$ Bonaventure, 1; Johannis de Caulibus, 7: "et completa circulacione reincipiens iterum, dulci ac suaui gustu ruminans ea, in arcano pectoris sui prudenti consilio collocabat." This treatise survives in two hundred manuscript copies and had fifty-two editions published in Italy between 1465 and 1550: Schutte, 100-04. See Quiviger, 2003, 75; Biernoff, 138.

${ }^{27}$ Ringbom, 20.
} 
Fidei Veritate (Triumph of the cross, 1497), images act as an aid for men in order to approach the deity and achieve divine knowledge, and devotion is increased if we can see a representation of Christ's life "in front of the eyes of our mind." ${ }^{28}$

Central to the role of vision in fifteenth-century devotion, then, was the hierarchical distinction between outer and corporeal versus inner and spiritual sight. Through contemplation of sacred images, the pious could proceed upward from corporeal to spiritual vision, spurred on to greater love for the divinity and coming nearer to a true understanding of the divine. As of yet, the equivalent role of the sense of hearing, and of sacred music addressed to that sense, has not enjoyed the same sustained attention, at least as regards fifteenth-century Italy. ${ }^{29}$ However, the role of hearing will prove essential to understanding fully the significance of the musical decorations in the Gualenghi-d'Este Hours, and also has broader implications for the aesthetics of sacred music in the period.

In fact, the religious conception of hearing and its role in devotional practice exhibit several important similarities with those of sight. The various aspects are encapsulated rather neatly in the story of an auditory vision, close in time and place to the Gualenghi-d'Este Hours, experienced by Caterina Vigri, later known as Saint Catherine of Bologna (1413-63). Caterina was raised at the court of Ferrara and became a nun in the convent of Corpus Domini there, later moving to the convent of Corpus Domini in Bologna. She was the author of a popular spiritual treatise, Le sette armi spirituali (The seven spiritual weapons, 1438, rev. 1450-56), and after her death her incorrupt body became the focus of a popular cult. ${ }^{30}$ She is included among the suffrages at the end of the Gualenghid'Este Hours. Caterina's mystical experiences are described in her own treatise, and also in two popular contemporary biographies: the Specchio di illuminazione (Mirror of illumination), written in 1468 by her companion, the nun Illuminata Bembo (ca. 1410-96), for a monastic audience; ${ }^{31}$ and Giovanni Sabadino degli Arienti's (ca. 1445-1510) Gynevera de le Clare donne (Ginevra: On famous women), written in 1472 for a courtly audience and containing the lives of thirty-three women, among which Caterina's is the longest.

${ }^{28}$ Savonarola, 295 (1.2.20): “dinanzi alli occhi della mente nostra." For more on Savonarola's ideas about the use of images in private devotion, see Steinberg, 47-52.

${ }^{29}$ Studies addressing the sense of hearing and musical perception in the late Middle Ages and Renaissance directly, all in general terms, include Burnett, Fend, and Gouk; Filippi, 17-34; Pietschmann, 2015. Studies addressing the topic more obliquely include Brown; Brothers; Blackburn, 1997; Dean, 1997; Pietschmann, 2013; Williamson.

${ }^{30}$ The treatise was printed in five editions between 1475 and 1540: see Schutte, 121-22; the modern edition is Vigri.

${ }^{31}$ On the wide circulation of this biography see Mostaccio's introduction to Bembo, xxxvii; Spano, 736. 
In the Specchio di illuminazione, Illuminata Bembo recounts an episode in which Caterina was gravely ill and close to death but survived because of the intensive prayers of one of the nuns. Illuminata explains that Caterina had a vision: "My spirit was stolen and taken to a place of such amazing and wonderful beauty that there is no human tongue that could ever express it." ${ }^{\text {"3 }}$ There, she saw God in majesty, surrounded by the Virgin Mary, other saints, and a multitude of angels. One of the angels was singing to the accompaniment of a "violeta." ${ }^{33}$ The sound coming from the strings echoed the words "et gloria eius in te videbitur" ("and his glory will be seen upon you"). ${ }^{34}$ The music triggered an ascending movement of her soul: "Upon hearing this sound it seemed to me that my soul was starting to leave my body." ${ }^{35}$ After coming back to her senses, she was so affected by this experience that she asked the nuns to find her a violetta. She played it obsessively, re-creating on earth the music performed by the angel in heaven. Illuminata, who was a witness to these events, recalls that "playing on it several times she seemed to melt like wax before the fire, now singing, now sitting in silence with her face towards the sky." ${ }^{136}$ The effect of the music upon her was so powerful that "she seemed to transform herself into God, and she became so happy that when the nuns, coming and going, spoke with her in turns, she did not move at all and kept playing, and while playing she lifted her face towards the sky, and whatever was said to her she had ears for none of it." ${ }^{37}$

A number of ideas can be found in this story that enjoyed wide circulation and purchase in the fifteenth century across a great range of textual sources and that effectively shaped the experience of hearing sacred music in the period. Caterina was allowed to observe and hear with her spiritual senses the celestial liturgy sung and played by the angels in heaven. The role of the music she heard

\footnotetext{
${ }^{32}$ Bembo, 65: "fu rapito lo spirito mio e menato in uno prato de tanta mirabile e maravegliosa belezza che non è lingua humana che mai lo potesse exprimere."

${ }^{33}$ Terms for stringed instruments were used imprecisely at this date so it would be unwise to identify a specific instrument with Caterina's violetta (the more conventional spelling), but we can probably assume it to be a small bowed stringed instrument.

${ }^{34}$ Bembo, 66. The passage comes from Isaiah 60:2 and the full text (verses 1-2) is a responsory for the Feast of the Epiphany, with an associated plainchant.

${ }^{35}$ Bembo, 66: "udendo questo suono mi parve l'anima se comenciasse a partire dal corpo."

${ }^{36}$ Ibid.: "e quella più volte sonando lei, parea tuta se deleguase como fa la cera al fuocho, ora cantando, hora stava con la facia verso el cielo stando como muta." In his very similar account of the same story, Arienti, 228-29, adds that Caterina's performance on the violetta "recalled the holy lyre of the holy King David" ("ricordare facea la sancta lira del divo re Davit").

${ }^{37}$ Bembo, 61: "e parea tuta se transformase in Dio e in tanta iubilatione divenia, che andando e venendo le sore, e parlando intorno a lei, lei mai non mutava suo costume e pure sonava, e sonando levava la fatia al ciello, e fussili dito quelle se volesse non dava orechie a niuno."
} 
within the context of the celestial liturgy was to enhance the effect of the liturgical text. When returned to her corporeal existence, Caterina undertook devotional music making addressed to her corporeal sense in imitation of that of the angel. The effect of sacred music - both that of the angels and that made in imitation by Caterina - was to draw Caterina closer to God, either literally, by prompting a spiritual ascent to heaven, or imaginatively, by elevating her mind toward the divine. This effect generated an experience of heavenly joy, and caused her temporarily to become ignorant of her earthly existence.

Obvious point though it may seem, it is impossible to overestimate the importance for the fifteenth-century conception of sacred music that the angels were understood to sing and make music in praise of God. ${ }^{38}$ The Milanese choirmaster Franchino Gafori (1451-1522) makes precisely this point in his Theorica Musice (Theory of music) printed in 1492, asserting that "nothing must be valued as either greater or more worthy to the intellect than this celestial, angelic, and almost divine harmony, whose pitches, even if the human ear shuns to hear them, I believe nevertheless that those spirits incessantly jubilate to the highest: Holy, holy, holy, Lord God of Hosts. ${ }^{39}$ As Gafori here reminds his reader, the Catholic liturgy includes several important hymns that are identified as angelic songs in their biblical origins. The Sanctus, Gafori's example, named "hymnus angelicus" in medieval manuscripts ${ }^{40}$ derives from Isaiah 6:3, where the prophet sees the seraphim singing to God: "Holy, holy, holy is the Lord of hosts; the whole earth is full of his glory!" "11 Similarly, the "Gloria in excelsis Deo" derives from Luke 2:13-14, when a celestial army comes to sing to the newborn Christ: "Glory to God in the highest, and on earth peace among those with whom he is pleased."

The effect of performing angelic songs during Mass is obviously to make the earthly choir into a reflection or imitation of the heavenly one, just as Caterina imitated with her violetta the angelic music she saw and heard in her vision. Several authors describe the unity between the Church Militant on earth and the Church Triumphant in heaven that music can achieve. Saint John Chrysostom (ca. 347-407) provides a clear image of the unified chant of the heavenly and earthly choirs in one of his homilies: "Above, the hosts of angels sing the glory;

\footnotetext{
${ }^{38}$ On angels in the Renaissance, see Gill; from a musical perspective, see Huck.

${ }^{39}$ Gafori, 1993, 21; Gafori, 2005, 30: "Nichil profecto aut maius aut intellectu dignius hac
} celesti angelicaque ac pene diuina harmonia aestimandum puto cuius uoces et si humana auris audire refugit incessabiliter tamen altissimo spiritus ipsos iubilare et Sanctus Sanctus Sanctus dominus deus sabaoth decantare."

${ }^{40}$ Iversen, 191.

${ }^{41}$ English Standard Version (ESV), Isaiah 6:3; Biblia Sacra Vulgata, Isaias 6:3: "Sanctus, Sanctus, Sanctus, Dominus exercituum plena est omnis terra gloria eius."

${ }^{42} \mathrm{ESV}$, Luke 2:14; Vulgata, Lucas 2:14: "Gloria in altissimis Deo et in terra pax in hominibus bonae voluntatis." 
on earth, men form choirs in the churches and following their example, likewise, they sing the songs of praise. Above, the seraphim thrice proclaim the hymn of the Sanctus; on earth, the multitude of men make known the same hymn and in common, both the heavenly and the terrestrial are brought together in a joyous assembly; there is one act of gratitude, one exultation, one vigil of delight of the choirs." ${ }^{43}$ The French theologian Johannes Beleth (fl. 1135-82) — whose guide to the Christian liturgy, Summa de ecclesiasticis officiis (Summary of the ecclesiastical offices, 1160-64), remained authoritative and enjoyed a printed distribution in fifteenth-century Italy—reiterates this account of musical union, stating that "we sing the songs of the angels, because we do not doubt that through them those on earth are united with those in heaven." ${ }^{\text {"44 }}$ A number of anecdotes dramatizing the interaction of heavenly and earthly liturgies were transmitted in the ubiquitous Legenda aurea (The golden legend, ca. 1260) by the Italian Dominican and archbishop of Genoa Jacobus de Voragine (ca. 1230-98). ${ }^{45}$ In the life of Saint Gregory, for example, an angel answers to his "Pax Domini" with an "Et cum spiritu tuo!" pronounced in a loud voice. ${ }^{46}$ In the life of Saint Thomas of Canterbury, during the Mass of the dead, choirs of angels interrupt the singers and begin to sing the Mass of the martyrs. ${ }^{47}$ Voragine reminds his readers that the singing of the Kyrie signifies that "we are to enter the company of the nine orders of angels. ${ }^{\text {"48 }}$ The Naples-based music theorist Johannes Tinctoris (ca. 1430-1511) sums up this discourse effectively in his Complexus Effectuum Musices (Compendium of music's effects) of 1473, noting that "music makes the Church Militant like the Church Triumphant."

${ }^{43}$ John Chrysostom, 97 (In illud, Vidi dominum, homily 1): "In supernis exercitus angelorum canunt gloriam: in terris homines in ecclesiis choros agentes ad illorum exemplum eadem canunt laudis cantica. In supernis Seraphim ter sanctum illum hymnum clamant: in terris eumdem hominum promit multitudo, communiterque tum caelestium, tum terrestrium festivus conventus congregatur: una gratiarum actio, una exsultatio, una gaudentis choreae statio."

${ }^{44}$ Beleth, 81 (Summa de ecclesiasticis officiis 45.18-19): "Cantica angelorum cantamus, quia per hoc sacrificium terrena iungi celestibus non dubitamus."

${ }^{45}$ A copy of the Legenda aurea was in Borso d'Este's library: Bertoni, 383 (item 7, "Cronicha fratris Januensis de Voragine"). It was printed in Italy in the vernacular in twenty-seven editions between 1475 and 1548: see Schutte, 321-23. On the Legenda aurea, see Reames. For variations in the text, see Maggioni.

${ }^{46}$ Voragine, 2012, 178 (Legenda aurea 46.9, "De sancto Gregorio").

${ }^{47}$ Ibid., 61 (Legenda aurea 11.3, "De sancto Thoma cantuariensi").

${ }^{48}$ Ibid., 772 (Legenda aurea 182, "De dedicatione ecclesiae"); Voragine, 1850, 846: "ut ad societatem novem ordinum angelorum perveniamus."

${ }^{49}$ Cullington and Strohm, 60 (Tinctoris, Compexus effectuum musices 58); ibid., 77: "musica ecclesiam militantem triumphanti assimilat." Several of Tinctoris's effects, including this one, were borrowed from the Expositio regulae Sancti Augustini of the thirteenth-century Dominican Humbert of Romans, as demonstated in Wegman, 2009. 
This idea was not only a theoretical construct in fifteenth-century Italy, but to a substantial extent shaped the way in which Italians experienced, and reported on the experience of, sacred music. From an expert perspective, Gafori writes concerning the singing of melismas in plainchant in his Practica Musicae (Practice of music, 1496) that "the Ambrosians call it by the general name melody, as they in mind and spirit rehearse the divine Trinity and (as they say) the angelic harmony." Simpler and more direct formulations of the connection between heavenly and earthly choirs were, in effect, the standard positive critical response to the performance of sacred song. In the Specchio di illuminazione, for example, Illuminata Bembo describes angels participating in the nuns' singing: "So many angelic spirits descended from heaven and came together with us to praise the divine grace. ${ }^{.51}$ Similarly, if more poetically, in response to the performance of Guillaume Du Fay's motet Nuper Rosarum Flores during the consecration of Santa Maria del Fiore in Florence in 1436, Giannozzo Manetti (1396-1459) wrote that "it seemed not without reason that the angels and the sounds and singing of divine paradise had been sent from heaven to us on earth to insinuate in our ears a certain incredible divine sweetness." ${ }^{52}$ In the immediate environs of the Gualenghi-d'Este Hours, writing in 1472 the lawyer and Este administrator Francesco Ariosto "il Peregrino" (1415-84) described the singing of a group of youths before an image of the Madonna Lactans in Ferrara in similar terms: "Kneeling with the greatest and most fitting reverence, with a marvellous or even inestimable harmony of melodies, such that to others they seemed to be an angelic choir, publicly in full sight of the people, with great ceremony they sang most sweetly and distinctly laude dedicated to the most holy majesty." ${ }^{\text {t3 }}$

Read in light of the theological sources reviewed above, these accounts describe a scenario in which the corporeal sensory experience of earthly sacred music brings about an elevation of the soul such that the spiritual sense of hearing is able to apprehend the celestial liturgy. In this respect, contemporary

${ }^{50}$ Gafori, 1969, 61, translation substantially altered (Practica Musicae 1.13); Gafori, 1496, fol. $5^{\mathrm{v}}$ : "diuinam scilicet trinitatem et angelicam harmoniam (vt ipsi aiunt) mente et animo interea percurrentes."

${ }^{51}$ Bembo, 29: "son tanti spiriti angelici desesi de cielo e venuti insieme con nui a laudare la clementia divina."

${ }^{52}$ English translation after Pietschmann, 2013, 276; ibid., 277n7: "ut angelici ac prorsus divini paradisi sonitus cantusque demissi caelitus ad nos in terris divinum nescio quid ob incredibilem suavitatem quandam in aures nostras insusurare non immerito viderentur."

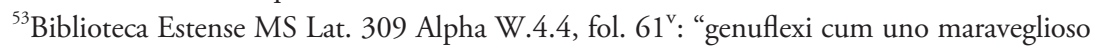
anzi inestimabile conceto de melodie che an vi altri parea uno angelico choro publicamente inconspecto del populo cum grande cerimonie cantavano suavissi.e et denotissi.e laude dedicade ala so sacra maiestade." This text was completed in three stages between 1472 and 1476; the quotation is taken from the earliest stage. There is no printed edition. 
understandings of sight and hearing are strikingly well aligned: through meditation on representations of the divine presented to the bodily sense, the devotee is able to engage their higher spiritual sense and thereby achieve a more direct and truthful understanding of the thing represented. Seen (or rather heard) through this lens, sacred song can be understood as an earthly representation of angelic song, just as a painting of the Madonna and Child is an earthly representation of the deity and his mother.

This conception of sacred music relies on the operation of an inner, spiritual sense of hearing capable of accessing musical experiences that are, from an earthly perspective, silent-a conception similar to Augustine's distinction between inner and outer levels of vision, described above. ${ }^{54}$ This inner ear is encapsulated in the metaphor of the music of the heart, discussed by Beth Williamson both from the perspective of viewing musical notation and internalizing the song or understanding its symbolic meaning, and from that of understanding silence not as the absence of music, but rather as music that continues in the heart. ${ }^{55}$ Captured within this metaphor, of course, is not only the reception of music, but also its production, and accordingly the inner sensorium is equipped not only with ears, but with a voice. From a Christian perspective, this idea rests ultimately on Saint Paul's letter to the Ephesians, in which he describes the faithful "addressing one another in psalms and hymns and spiritual songs, singing and making melody to the Lord with your heart," and also 1 Corinthians, in which he observes that "I will pray with my spirit, but I will pray with my mind also; I will sing praise with my spirit, but I will sing with my mind also." 57 Taking Paul's lead, this notion was endorsed by influential church fathers. Commenting on Paul, Jerome notes that "certainly, the psalm pertains to the body and the song to the mind. And we ought therefore to sing, to make melody and to praise the Lord more with spirit than the voice." ${ }^{158}$ Similarly, Augustine describes "the brethren singing together with great earnestness of voice and heart," $"$ and admonishes his readers to "let that be pondered in the

${ }^{54}$ The corporeal silence of angelic song is noted by Gafori, 2005, 30: "si humana auris audire refugit" ("even if the human ear shuns to hear them").

${ }^{55}$ Williamson, esp. 13-21, 31-37.

${ }^{56} \mathrm{ESV}$, Ephesians 5:19; Vulgata, Ephesios 5:19: "loquentes vobismet ipsis in psalmis et hymnis et canticis spiritalibus cantantes et psallentes in cordibus vestris Domino."

${ }^{57}$ ESV, 1 Corinthians 14:15; Vulgata, 1 Corinthios 14:15: "quid ergo est orabo spiritu orabo et mente psallam spiritu psallam et mente."

${ }^{58}$ McKinnon, 145; Jerome, 1859, 528 (Commentariorum In Epistolam Beati Pauli Ad Ephesios 3.5.19): "Vel certe . . p psalmus ad corpus: canticum refertur ad mentem. Et canere igitur et psaltere, et laudare Dominum magis animo quam voce debemus."

${ }^{59}$ Augustine, 1886, 134 (Confessiones 9.7.15); Augustine, 1981, 141: "exhortationis celebrare magno studio fratrum concinentium uocibus et cordibus." 
heart which is uttered by the voice" when singing psalms and hymns. ${ }^{60}$ For Augustine, the heart is the verbal center of the self: he listens with the ears of the heart, confesses in his heart, and speaks with his heart's voice. ${ }^{61}$

Later texts treat the inner ear and the inner voice as a commonplace. In the Legenda aurea, for example, Saint Cecilia sings "in her heart to the Lord alone" during her wedding, ignoring the outer music of terrestrial instruments - this is, of course, the subject of Raphael's famous painting of Saint Cecilia (ca. 1516, Pinacoteca Nazionale, Bologna). ${ }^{62}$ Similarly, in Le sette armi Caterina Vigri describes how a sonic battle with the devil took place inside her heart: "Day and night she could not remove it [the sound] from her heart." ${ }^{\text {"33 }}$ Meanwhile, her companion, Illuminata Bembo, uses the metaphor of the ears and the eyes of the mind repeatedly: "Look and open the ears of the intellect," ${ }^{, 64}$ "see with the intellectual eye." Savonarola—who favored sacred monody while vehemently opposing elaborate polyphony - distinguishes between interior and exterior forms of worship in relation to musical practice. Echoing the conventional relationship between the corporeal senses and their spiritual counterparts, he contrasts mental prayer (the most effective way to contemplate God) with outward religious ceremony, the value of which lies only in its ability to prompt an inner state of worship. ${ }^{66}$

As Caterina Vigri found with her violetta, engaging the inner sensorium through the audible imitation of angelic music has the effect of elevating the spirit, bringing one closer to the divine. The same idea can also be found in mirror image: in the contemporary descriptions of the experience of listening to sacred music cited above, the earthly imitation of sacred music is said to draw angels down from heaven to augment the earthly choir. The capacity of music to draw the earthly upward and the divine downward is described very concisely by Marsilio Ficino (1433-99) in his De Vita Libri Tres (Three books on life) of 1489. Having established that music is "a most powerful imitator of all things," Ficino notes that "when it imitates the celestials, it also wonderfully arouses our spirit upwards to the celestial influence and the celestial influence downwards to our spirit.."67

${ }^{60}$ Augustine, 1886, 565 (Epistulae 211.7); Augustine, 1841a, 960: "in corde quod profertur in voce."

${ }^{61}$ Jager, 6.

${ }^{62}$ Voragine, 2012, 704 (Legenda aurea 169, "De sancta Caecilia"); Voragine, 1850, 771-72: "in corde soli domino decantabat."

${ }^{63}$ Vigri, 40 (Le sette armi spirituali 7.111): "dì e nocte non se lo poseva estripare del core."

${ }^{64}$ Bembo, 14, 46: "Vedi e apri le orechie dello intellecto."

${ }^{65}$ Ibid., 16: "vedi con l'ochio inteletuale."

${ }^{66}$ Macey, 1998, 92.

${ }^{67}$ Ficino, 1989, 359 (De Vita Libri Tres 3.21); Ficino, 1529, 211: "virtute quando coelestia imitatur, hinc quidem spritum nostrum ad coelestem influxum, inde vero influxum ad spiritum mirifice provocat." 
When acting to bring the divine and the human into closer proximity, music is in fact the agent of mystical experience, as one of Caterina Vigri's temptations reveals. Caterina fights with the devil in a "great battle of sound," from which torment she is delivered during Mass. ${ }^{68}$ At the moment of the Sanctus she hears the angels singing, and their melody is so sweet that "suddenly, her soul started coming out of her body." ${ }^{\text {"69 }}$ It is the beauty of the music — "so sweet that angelic song seemed to her, that no tongue is able to express it and no mind to imagine it"- that generates this uplifting movement of her soul. She describes the duration of the angelic song as being as brief as "the blink of an eye." The mystical experience is triggered immediately as the sound reaches her ears-"as soon as it entered the hearing of her ears" —and it begins with her forgetting about herself and everything around her- "she completely forgot about herself and all things created as if they never were"-and culminates with the ascending movement of her soul. ${ }^{70}$

In addition to prompting divine encounters, music can also result from mystical experiences; sometimes it can do both at the same time, as in Caterina Vigri's experience with the violetta. A number of anecdotes in the Legenda aurea dramatize this kind of divine inspiration. Saint Ignatius, for example, heard angels standing on a mountain singing antiphons and he therefore made it a rule that antiphons should be sung in church. ${ }^{71}$ Elsewhere, a boy is carried to heaven, where he learns an angelic canticle, which he sings to the people upon his return. $^{72}$ While on trial in 1498, one of Savonarola's companions, Fra Domenico da Pescia, explained how another of the friars, Fra Silvestro Maruffi, had experienced a similar vision in which several angels taught him the song "Ecce quam bonum"; the song subsequently became one of the most recognizable features of the Savonarolan movement. ${ }^{73}$

In the broadest terms, the outcome of these various aspects of sacred musical experience-all of which were entirely conventional within the devotional culture surrounding the Gualenghi-d'Este Hours—is that music was readily seen as a highly desirable modality for devotional expression, rendering prayer more effective by elevating the mind and spirit of the orant. This general point is made most paradigmatically by Augustine in the Confessions, in which he

${ }^{68}$ Vigri, 40 (Le sette armi spirituali 7.111): "grandissima bataglia de sono."

${ }^{69} \mathrm{Ibid}$. (Le sette armi spirituali 7.112): "subito l'anima li comenzò a uxire del corpo."

${ }^{70}$ Ibid., 41 (Le sette armi spirituali 7.113): "tanto li seppe dolcissimo quello anzelicho canto, che non è lingua lo potesse esprimere nè mente immazinare," "uno batere d'ochio," "aussì tosto commo intrò nell'audito delle sue orechie," "smenticosse perfectamente si medesma e tutte le cosse create, commo mai non fosse state."

${ }^{71}$ Voragine, 2012, 141 (Legenda aurea 36.3, "De sancto Ignatio").

${ }^{72}$ Ibid., 289 (Legenda aurea 70).

${ }^{73}$ See Macey, 1998, 24. 
acknowledges that "our minds are more devoutly and earnestly elevated into a flame of piety by the holy words themselves when they are thus sung, than when they are not"; therefore, he allows that "by the delights of the ear the weaker minds may be stimulated to a devotional frame." ${ }^{" 74}$ Tinctoris conveys the same point more concisely in his Complexus Effectuum Musices, noting that music has the effect of "stirring the feelings to devotion." In his De Vita Libri Tres Ficino even goes so far as to propose music as the modality toward which prayer should aspire: "A prayer, when it has been suitably and seasonably composed and is full of emotion and forceful, has a power similar to a song." ${ }^{, 76}$ The recommendation of music came, however, with the important proviso that devotional music making should aim to engage the inner sensorium primarily, treating corporeally audible music merely as a means to that end: Augustine and Jerome make this very clear, as do fifteenth-century authorities such as Savonarola and the Florentine theologian Giovanni Carioli. ${ }^{77}$

This last point is worth stressing, because it will be central to the ensuing discussion of musical elements in the decoration of the Gualenghi-d'Este Hours. Silent musical experiences arising from and addressed to the inner voice and the inner ear were considered not only possible, but in a sense preferable to embodied audition as a component of devotional practice-earthly sacred music imitated the song of the angels, which, after all, was itself silent, and Augustine's sensory hierarchy is completely unambiguous in assigning the higher status and the greater pious efficacy to the inner sensorium. Just as in the absence of visual art the devotee could call an image of Christ before their mind's eye, assisted by their memory of images seen, and through contemplation of the mental image achieve a higher understanding of the deity, so the same devotee could call before their mind's ear, assisted by their memory of music heard, a sacred song and experience the revelatory companionship of the angels. Just as in calling forth a mental image of Christ the devotee was not only viewing, but authoring that image, similarly in summoning a song of the heart the devotee was not only hearing, but singing. The precise nature of such inner musicianship, however,

\footnotetext{
${ }^{74}$ Augustine, 1886, 156 (Confessiones 10.33.49-50); Augustine, 1981, 181-82: “dum ipsis sanctis dictis religiosius et ardentius sentio moueri animos nostros in flammam pietatis, cum ita cantantur, quam si non ita cantarentur" "ut per oblectamenta aurium infirmior animus in affectum pietatis adsurgat."

${ }^{75}$ Cullington and Strohm, 58 (Tinctoris, Compexus Effectuum Musices 10); ibid., 75: "Animos ad pietatem excitare."

${ }^{76}$ Ficino, 1989, 363 (De Vita Libri Tres 3.21); Ficino, 1529, 224: "Memento vero orationem apte et opportune compositam, et affectu sensuque plenam atque vehementem, similem cantibus vim habere."

${ }^{77}$ Relevant passages from Augustine, Jerome, and Savonarola are quoted earlier in this essay; for Carioli, see Wegman, 2005, 17-48, esp. 27.
} 
must have varied very greatly with individual devotees' musical experience and expertise, inhabiting a spectrum from actual songs replayed in memory, to song in the abstract as a way of concieving of a text that was not in fact melodicized in any literal sense, sounding or mental.

\section{EXEMPLIFYING SILENT MUSIC}

In the Gualenghi-d'Este Hours, the beginning of the Office of the Virgin, the core text in any book of hours, is marked with a substantial decorative ensemble. ${ }^{78}$ On the left side of the opening, the Annunciation to the Virgin is presented in a panel (fig. 1). The angel, as is conventional, has discovered the Virgin in the act of reading from a book in an attitude of prayer (which, of course, is exactly what the book's owner is doing when viewing this image). The angel kneels respectfully, gaze lowered, as he delivers his biblical salutation, which is abbreviated in an inscription at the head of the image: "AVE GRACIA PLENA."

Immediately beneath the image, a scroll bearing the motto "VBI DEVS EST IBI PAX ET AMOR" ("where God is, there are peace and love") encircles a dove, a symbol of peace and also the Holy Spirit, in which guise it often appears in Annunciation scenes as the means by which God's grace descends to Mary. The dove and motto are flanked by two peacocks, birds whose flesh was traditionally said not to decompose after death-here an allusion to the Assumption of the Virgin — and which were thought to live in heaven. At the top left corner, a gourd, linked with the stories of Endymion and Jonah, is another reference to heavenly repose. Immediately beneath the gourd, a youthful angel bursts forth in a golden radiance, stands on a swirling blue cloud, and bears a tangling scroll on which music notation is visible. A scroll on the righthand side of the Annunciation scene bears the motto "FORTIS EST INASPERI NON TURBARI" "it is brave not to be troubled in difficult times"), which may have been used by Andrea, as Barstow suggests, or may refer directly to the biblical account of the Annunciation in Luke 1:26-38: immediately after the verse that is the source of the Angelic Salutation, Mary is described as "turbata," but she quickly overcomes her fear, demonstrating her fortitude. ${ }^{79}$ The righthand, textbearing page (fig. 2) declares that "Here begins the Office of the Blessed Virgin Mary following the use of Rome," and then matins begins with a verse and response from Psalm 50 (Biblia Sacra Vulgata numbering): "Domine labia mea aperies / et os meus an[n] untiabit laudem tuam" ("Lord, you will open my lips, / and my mouth will declare your praise"; from Psalm 51 in English Standard

\footnotetext{
${ }^{78}$ On the decoration of the Office of the Virgin in Italian books of hours, see, most recently, Stocks.

${ }^{79}$ Barstow, 206.
} 


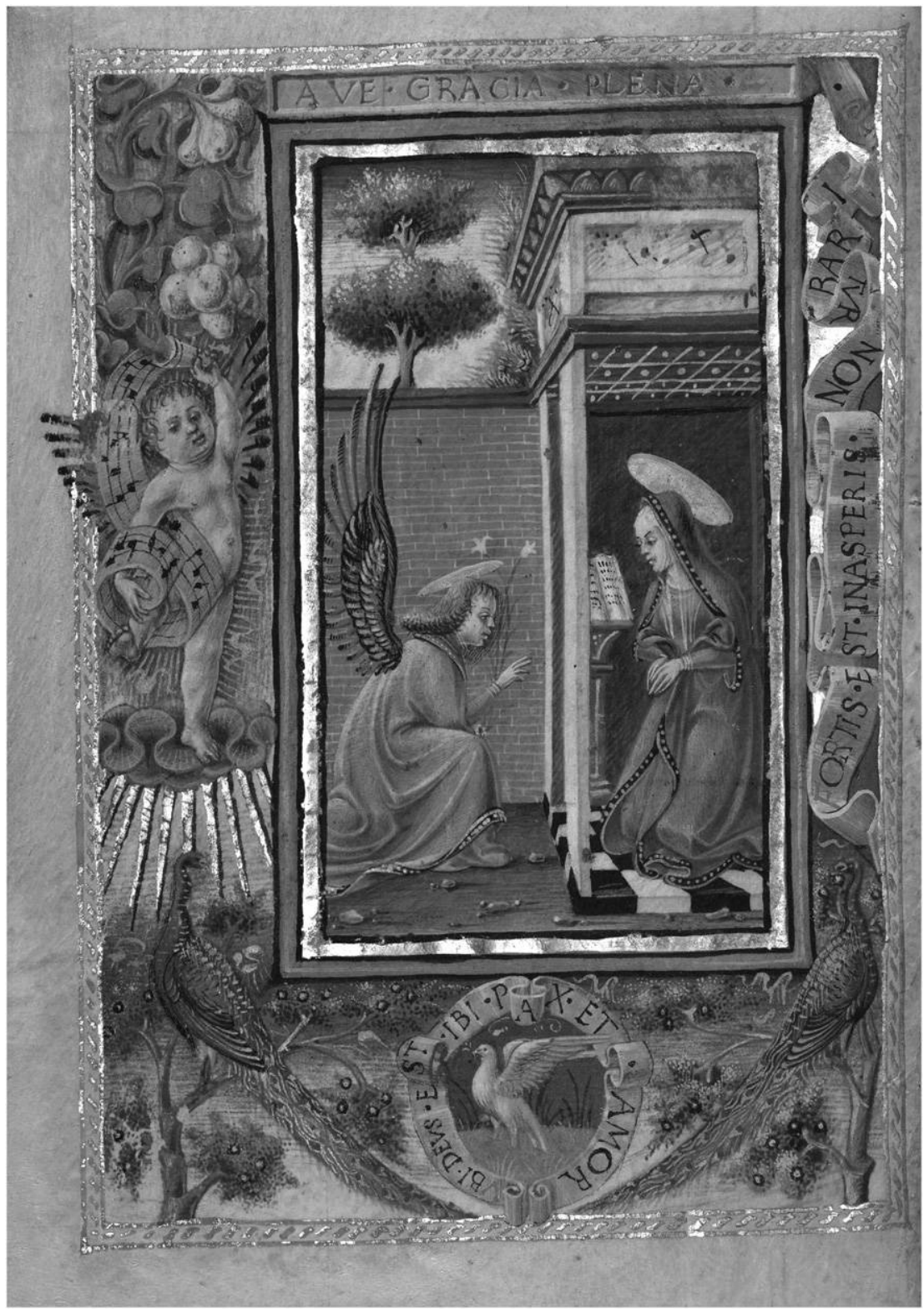

Figure 1. Taddeo Crivelli. The Annunciation, ca. 1469. J. Paul Getty Museum, MS Ludwig IX 13, fol. $3^{\mathrm{v}}$. Digital image courtesy of the Getty's Open Content Program.

Version [ESV] numbering). In the initial $D$ is a miniature showing the Virgin and Child, to whom this biblical prayer should be addressed.

Music weaves in and out of this opening in a variety of ways. Matins opens with texts taken from a psalm, which is, of course, a biblical song composed and 


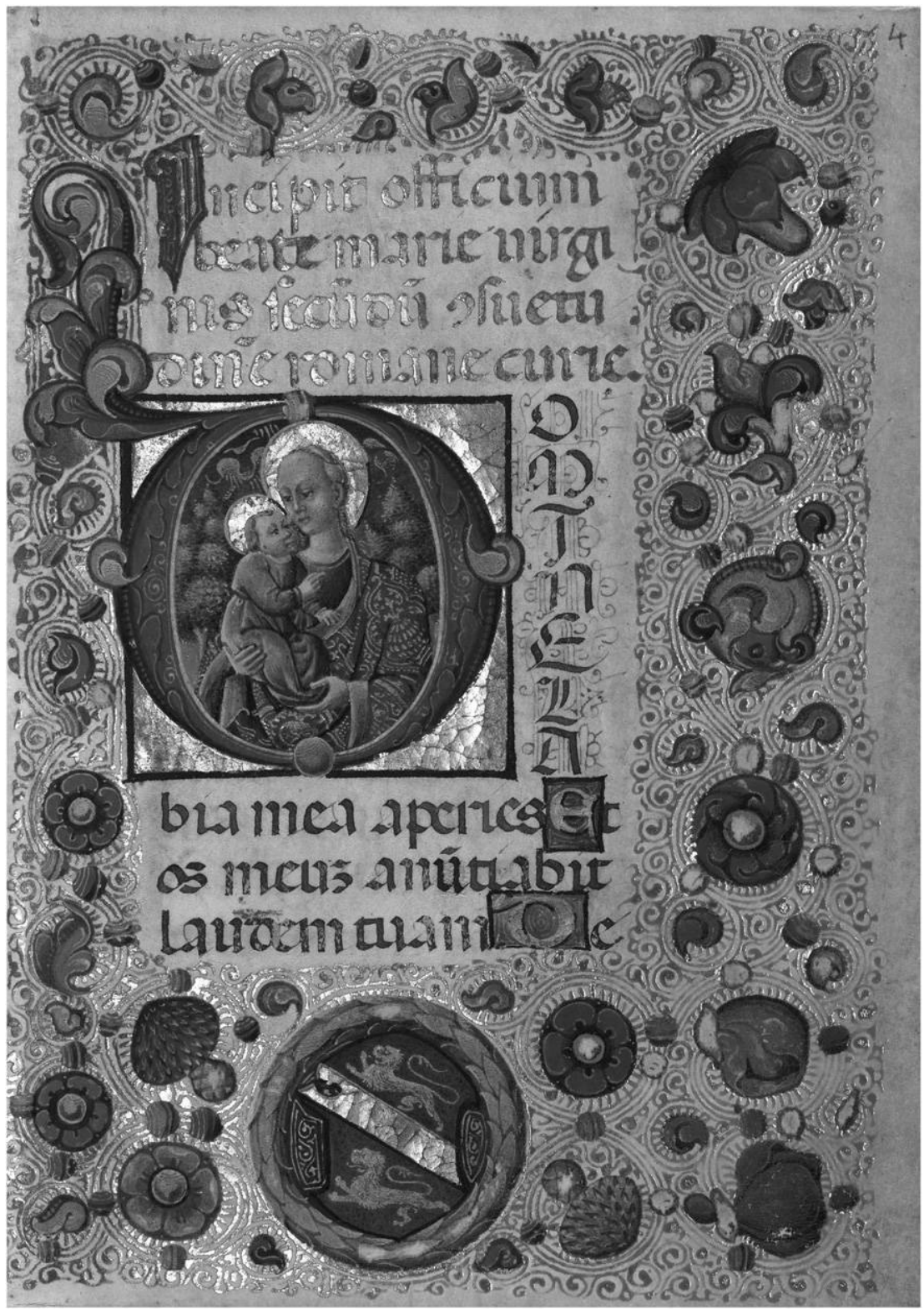

Figure 2. Guglielmo Giraldi. Initial $D$ with the Madonna and Child, ca. 1469. J. Paul Getty Museum, MS Ludwig IX 13, fol. $4^{\mathrm{r}}$. Digital image courtesy of the Getty's Open Content Program. 
sung by King David, even when (as here) presented without musical notation. ${ }^{80}$ This particular psalm text formed a part of the liturgy for both Passion Sunday and the second Sunday of Lent, and it circulated widely in two plainchant settings (one for each liturgical occasion). Thus, although presented in their book of hours without notation, Andrea and Orsina would have certainly heard this psalm sung in church and understood it to be a song both figuratively and literally. In reciting this psalm, the reader states their intention to "open their lips" and declare God's praise, an act that in the context of a psalm-that is, a song — can only be read as breaking into song. In reading this page, then, the book's owner breaks into a song (if here a figurative rather than a literal song) about breaking into song.

Meanwhile, on the facing page, the reader is reminded of the words uttered by the angel Gabriel, "Ave Maria gratia plena." That angels sing is already a familiar notion, and indeed this text enjoyed an extremely extensive circulation in a bewildering variety of plainchant settings, with a multitude of liturgical applications, first among them being of course the Feast of the Assumption of the Virgin. In numerous churches the Angelic Salutation was sung in a dramatic reenactment of the Annunciation known as the Missa aurea, celebrated on the Feast of the Annunciation or during Advent. ${ }^{81}$ The text was also frequently subjected to polyphonic setting as a motet-numerous surviving settings are approximately contemporary with the Gualenghi-d'Este Hours and the period of its use by its initial owners. ${ }^{82}$ Andrea and Orsina could not help but have viewed their Annunciation miniature in the knowledge that angels in general sing, and that this text in particular was often sung in church. The direct relevance of this message would have been clear as their performance of the

\footnotetext{
${ }^{80}$ The psalm from which the text "Domine labia mea" derives is attributed to David in its biblical context, but it is worth noting that other psalms not specifically attributed to David were also commonly connected with his authorship: for example, Psalm 1, which in many psalters was accompanied by a portrait of David, and Psalms 102 and 130, which were brought under David's authorship through inclusion among the seven penitential psalms (all ESV numbering).

${ }^{81}$ Musical aspects of this custom are discussed in J. A. Owens.

${ }^{82}$ To draw some examples from a celebrated set of sources from Trento: a three-voice setting by Reginaldus Libert is in Museo Provinciale d'Arte, Castello del Buonconsiglio MS 1379 (Trent $92_{1}$ ) of the 1430 s and 1440s (see Ward); a three-voice setting by Johannes Brassart appears in MS 1374 (Trent 871) of the 1430s and 1440s (see Wright, 1982 and 1986); an anonymous three-voice setting appears in MS 1376 (Trent 89) copied in the 1460s (see Wright, 1996); and two anonymous settings, one for three and one for four voices, are in MS 1378 (Trent 91) of the 1470s (see Wright, 1995). Further, Johannes Regis's two settings, for three and five voices, must date from around the same time as the Gualenghi-d'Este Hours (see Dumitrescu), as must that of Johannes Ockeghem (see Bernstein), and the settings by Loyset Compère and Josquin Des Prez (see Macey, 1989; Rifkin) from shortly after.
} 
Hours of the Virgin required them to recite the text "Ave Maria gratia plena" four times over the course of the following three openings.

Finally, of course, there is the music notation, which is presented in a blast of heavenly light as if the angel is delivering it to the reader directly from paradise (an interpretation supported by the Saint Gregory opening, discussed below). The artist gives a reasonably accurate simulacrum of contemporary neumatic notation, an unmeasured notation used exclusively for plainchant. Four of the basic note shapes of neumatic notation-the virga, punctum, pes, and clivis ${ }^{83}$ can be picked out quite distinctly. These neumes are arranged on a three-line staff rather than the usual four-line staff of chant notation, which most likely reflects a lack of expertise on behalf of the artist (although staff design retained a small degree of flexibility in the fifteenth century). Overall, the notation presented on the angel's scroll is nearly clear and accurate enough to transcribe (albeit with gaps where the scroll curls round), although transcription reveals the melodic design to be somewhat inept and quite unlike plainchant. The artist was evidently familiar with the shapes of notated plainchant (he had been involved in making service books) and intended to depict plainchant in particular, but did not set out to notate a real chant. ${ }^{84}$

Taken together, these musical elements reinforce one another in instructing the reader about the importance of music in devotional practice. As the most explicitly and literally musical element, the scroll of faux plainchant, emerging from paradise in the hands of an angel, reminds the reader of the musical nature of the celestial liturgy and of the angels who celebrate it. At the same time, the presence of heavenly plainchant prompts the reader to recall the status of the Angelic Salutation as both figurative and literal song-figurative in the sense that angels were thought to sing, and literal in the sense that these words were actually sung in church as plainchant. Similarly, the scroll of music reminds the reader that the psalm they are about to recite is in fact a song-again, both figuratively, in the sense that it is conceived as song in its biblical context, and literally, in the sense that it was sung as plainchant in church. These musical resonances embody a paradox, however. The music emerging from heaven looks like plainchant, but in fact it cannot be performed as plainchant: quite apart from the gaps, the shortcomings in melodic design, and the lack of a match to any known chant, there is no text (the central element in any liturgical chant). Similarly, although

\footnotetext{
${ }^{83}$ Virga and punctum indicate single notes; pes, two notes ascending; and clivis, two notes descending. Counting from the highest point of the angel's scroll, the first note is a virga, the third a punctum, and the fifth a close approximation of a clivis. Looking right to the other end of the scroll, curling round the angel's arm, the last note visible is a close approximation of a pes.

${ }^{84}$ J. Paul Getty Museum MS 88 is an illuminated initial by Crivelli, cut from a gradual, dated to the 1460s; in the 1470s he was responsible for decorating service books in Bologna: Toniolo, 178-81.
} 
the reader is reminded that the psalm they have to recite to begin matins is a song, the book does not invite the reader to actually sing it—no musical setting for the words is provided. How do we interpret an opening that urges us to sing, but declines to give us a song?

The resolution to this paradox is to be found in our analysis of the role of music in devotional practice. As discussed above, music was considered to be an effective and desirable vehicle for devotional expression, imitating the praise of the blessed in heaven and drawing the mortal mind and soul toward the divine. However, to be effective, devotional song need not take the form of a sounding performance; rather, following the instructions of Saint Paul, it was more important to sing in the heart, an act that could coincide with a sounding performance, but could equally be an act of silent meditation. Thus, the matins opening presents its texts as songs because, conceptually, that is what they are, and because, in terms of devotional practice, that is the nature the reader should aspire to give to them. No musical setting is provided because, again in terms of devotional practice, sounding performance is not essential to their nature as spiritual songs. The lack of music notation does not, of course, preclude a sounding performance of the chant as song, as Baroffio has pointed out; aside from the small number of books of hours in which musical notation is provided for some texts, a sounding performance may arise in circumstances where a reader knows the melody by heart, or can access it in a separate book. ${ }^{85}$ This kind of expert engagement with the texts as chants, however, can hardly be expected of lay owners like Andrea and Orsina, except conceivably in the case of psalms. The opening reminds the pious reader not literally to sing, but rather to conceive of its texts as song, accruing the spiritual benefits pertaining thereto, even when reciting them orally or mentally as speech. In its musical silence, this devotional music continued to emulate the praise of the angels, whose celestial song was inaccessible to mortal ears (that is, it was silent).

In keeping with the meditative and exemplary function of the images and texts found in books of hours, the elements of this matins opening aim to make an intervention in the reader's devotional practice, directing their efforts toward the most efficacious and praiseworthy performance of their piety. The miniature of the Annunciation plays an additional role in exemplifying the appropriate use and understanding of music. The archangel Gabriel, whose words "Ave Maria gratia plena" were commonly heard as liturgical and paraliturgical song, exemplifies the song of the Church Triumphant, of which the song of the Church Militant was supposed to be an imitation. Mary herself is depicted, as usual, discovered kneeling indoors in an exemplary attitude of prayer, a devotional book open before her on a lectern; her book is written in the single column of a book of hours rather than the double column layout of

\footnotetext{
${ }^{85}$ Baroffio, 55-56, 63-69.
} 
a missal or bible. ${ }^{86}$ Besides the musical notation in the margin next to this miniature and the psalm of the facing page, there is no specific indication in the image that Mary's devotional practice has a musical component, audible or silent. But, of course, Mary's paradigmatic devotional prayer was the psalm-like Magnificat from Luke 1:46-55, which was universally thought of as a song and indeed was regularly sung in church in both plainchant and polyphonic settings as part of vespers. ${ }^{87}$ In his De Inventione et Usu Musice (On the invention and use of music) of the very early 1480s, Tinctoris twice draws attention both to Mary's musicianship and to its exemplification in the Magnificat: "The most holy prophets composed hymns and poems by divine inspiration, such as ... the virgin Mary, 'My soul doth magnify the Lord"'; and later, "before he [Christ] was born she most delightfully sang that outstanding canticle Magnificat, composed by her (as we said before) in newness of spirit. For Augustine says this in his sermon on Christmas, 'Hear how our woman timbrel player will have sung; indeed she says, "My soul doth magnify the Lord."”" 88 Thus, whether specifically depicted as such or not, Mary's exemplary devotion could always be understood as musical in nature. The Magnificat text appears a few pages later in the Gualenghi-d'Este Hours at vespers in the Office of the Virgin, and again at vespers in the Office for the Dead.

Another female exemplar found elsewhere in the Gualenghi-d'Este Hours addresses the question of music in devotional practice more directly. Among the saints featured in the suffrages toward the end of the book is Saint Catherine of Alexandria, depicted as a fifteenth-century Italian noblewoman in a domestic interior (fig. 3) ${ }^{89}$ She is busy at her devotions, standing and placing her hand on a book covered in red morocco with a golden clasp, which lies open before her on a lectern, as if following the text or about to turn the page. The book holds her gaze, but above it is the object of her devotions: a statuette of the Virgin and Child in a niche set into the wall of her chamber. Her left hand rests on a torture

${ }^{86}$ Older books of hours tended to give Mary's book a double-column layout, and she was conventionally understood to be reading the prophecy of a virginal birth found in Isaiah 11 . See Duffy, 36.

${ }^{87}$ See, for example, Lerner; Dean, 2017.

${ }^{88}$ Tinctoris, De Inventione et Usu Musice 1.11: "sanctissimi prophete hymnos et odas inspiratione divina composuerunt, ut . . Maria virgo, 'Magnificat anima mea Dominum”; Tinctoris, De Inventione 2.20: "quom natus infans humanitus vagiret, superius ostendimus; etiam antequam nascereturcanticum hoc egregium Magnificat, ab ea (ut prediximus) in novitate spiritus compositum, amenissime cantavit. Nam hec Augustinus in sermone de Nativitate dicit, 'Audite quemadmodum tympanistria nostra cantaverit: ait enim, Magnificat anima mea Dominum."

${ }^{89}$ For an unknown reason, this miniature is presented in the manuscript with no accompanying text. The same applies to three other saints depicted in miniature in the suffrages section. 


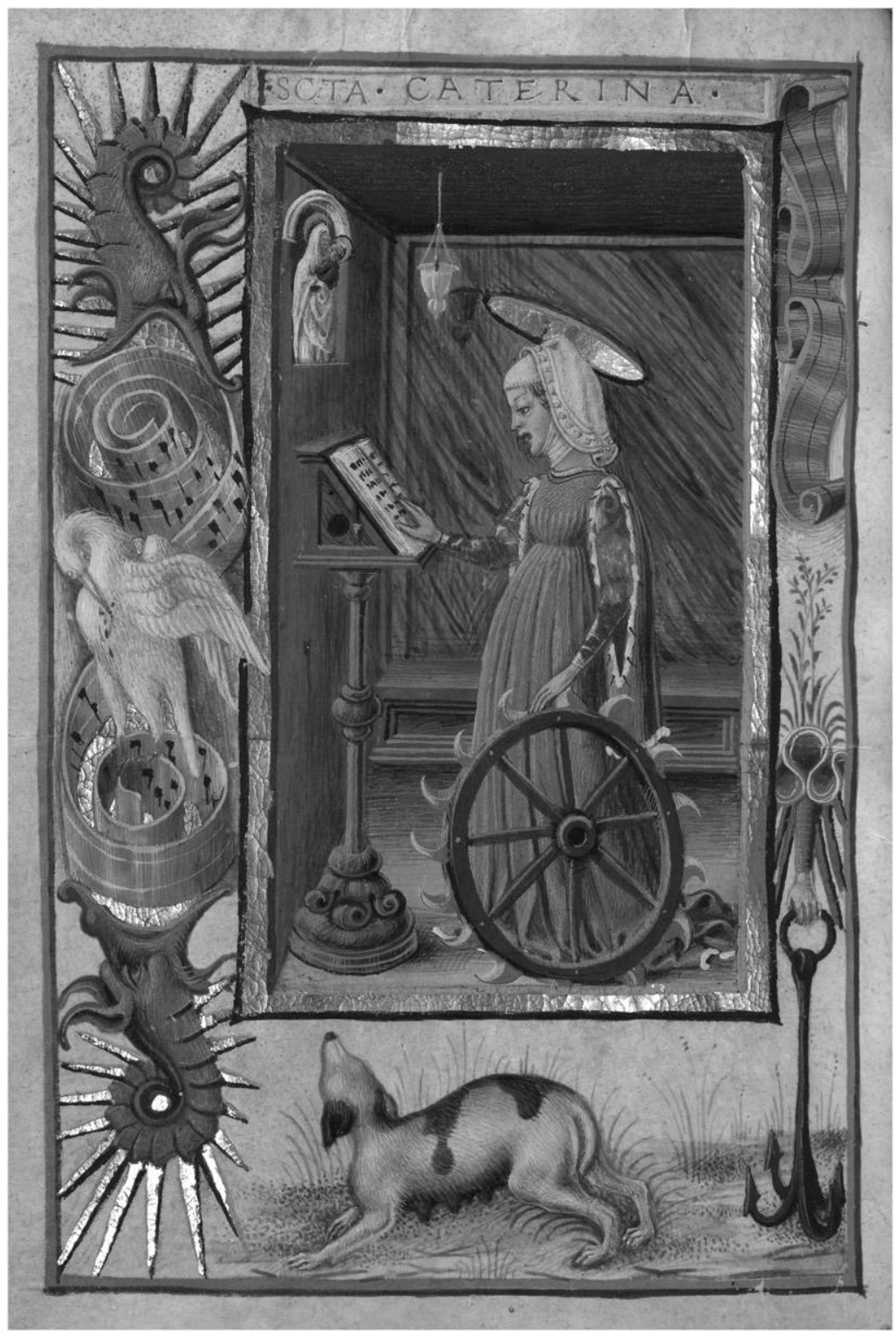

Figure 3. Taddeo Crivelli. Saint Catherine of Alexandria, ca. 1469. J. Paul Getty Museum, MS Ludwig IX 13, fol. $187^{\mathrm{v}}$. Digital image courtesy of the Getty's Open Content Program.

wheel, the only indication of her grizzly martyrdom. In the margin beneath the miniature is a dog, symbol of good faith and constancy, the praiseworthy qualities demonstrated by Saint Catherine during her encounter with the Emperor Maxentius (r. 306-12). The dog, conspicuously depicted as female, 
gazes up toward the lefthand border in which a pelican is shown piercing its own breast. The pelican is a common symbol for Christ's Passion, which viewers are invited to read as analogous to Saint Catherine's torture and martyrdom; but the combination of a bitch gazing at a pelican may also be intended to reflect Saint Catherine's particular faithfulness to Christ, emblematized in their mystic marriage. Behind the pelican, against a blue and gold background, is a scroll of music. As on the matins opening, the notation is neumatic, indicating plainchant, although it is a less sophisticated simulacrum than that found on the earlier opening, consisting almost exclusively of a single type of note head (virgae). This time the staff has only two lines and the swirling of the scroll is so pronounced that it is difficult to make anything of the music in transcription; nonetheless, what can be read does not match up to any particular chant.

The presentation of Saint Catherine in a realistic fifteenth-century elite setting suggests that she is being put forward as an example of virtuous behavior for a contemporary noblewoman-specifically, Orsina - to emulate. Her attire is very similar to that worn by Orsina herself in a miniature elsewhere among the suffrages that shows Orsina kneeling together with her husband and children before the local bishop-saint Bellinus (d. 1151), identified by name on the facing page (fig. 4). An address to Orsina specifically is also suggested by the anchor in the lower margin (fig. 3), a device of her natal family, the Este, which appears only on this page and one other (discussed below). The particular behavior that Saint Catherine is modeling is precisely that in which the reader is engaged when viewing the image: at prayer with the assistance of a devotional book. In this respect, Saint Catherine's position among the various saints depicted in the suffrages section is unusual: among twenty saintly miniatures, the majority are in monastic (nine) or clerical (three) dress, or that of a wild hermit (three). The only other saint presented in dress comparable to that worn by the Gualenghi-d'Este family in the Saint Bellinus miniature is the mysterious pseudosaint Ossanus, about whom we have no information at all.

Appropriately, Saint Catherine's hagiography marks her out as particularly suited to the task of modeling praiseworthy behavior for a fifteenth-century noblewoman. She was, of course, a princess, daughter of the rulers of Alexandria, who (according to the Legenda aurea) "was fully instructed in all the liberal arts." ${ }^{\prime 0}$ Aside from her study of the liberal arts, which would imply some knowledge of music, there is nothing in her story as transmitted in the Legenda aurea that would suggest a connection with music or provide a pretext for the scroll of plainchant in the margin. Rather than reading the scroll in terms of her hagiography, then, we should read it in terms of her modeling of exemplary devotional practice. The scroll of music tells us that, even though Saint

\footnotetext{
${ }^{90}$ Voragine, 2012, 720 (Legenda aurea 172, "De sancta Catherina"); Voragine, 1850, 789: "Catherina Costi regis filia omnibus liberalium artium studiis erudita fuit."
} 


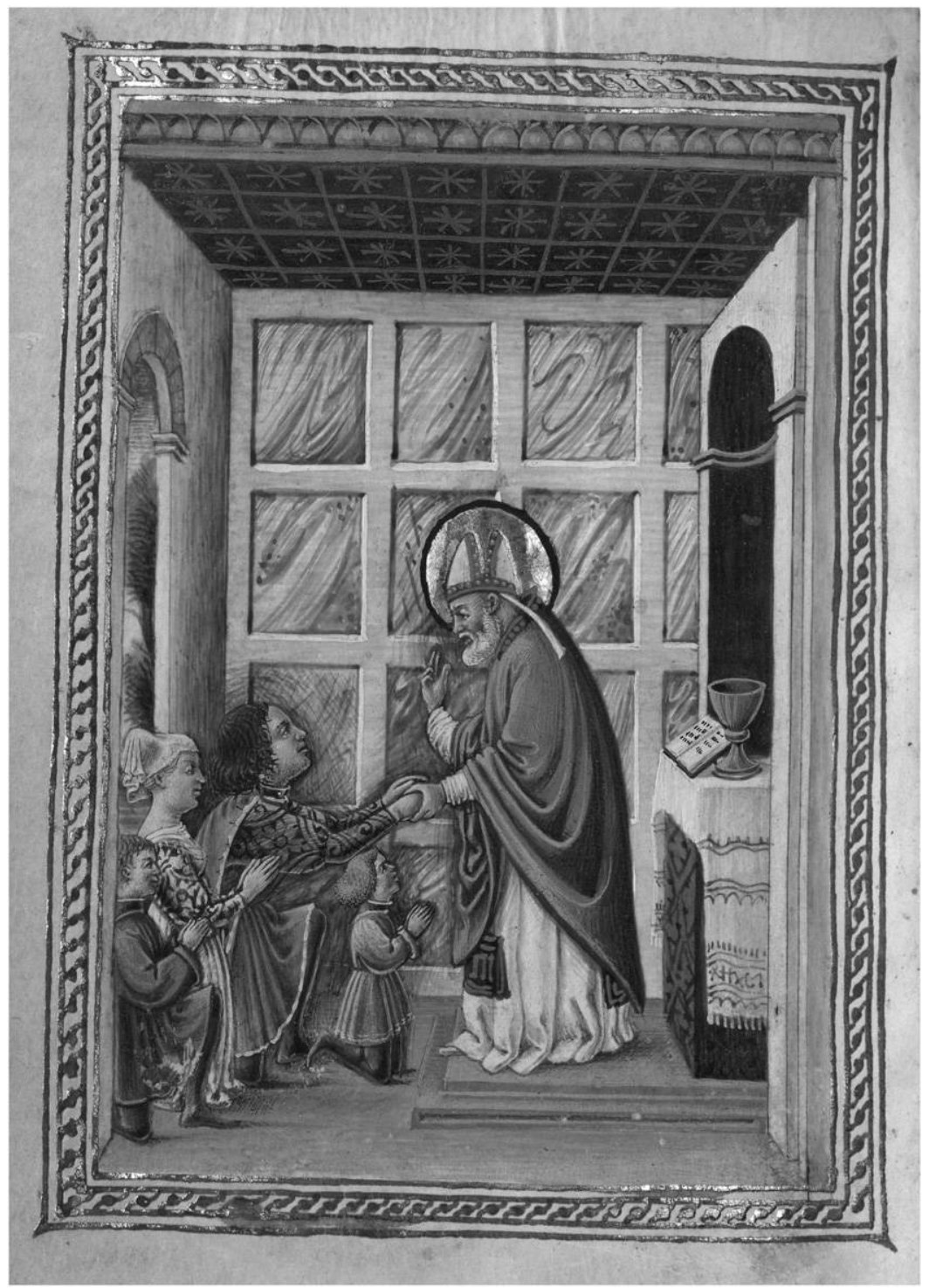

Figure 4. Taddeo Crivelli. Saint Bellinus with Andrea Gualengo, Orsina d'Este, and family, ca. 1469. J. Paul Getty Museum, MS Ludwig IX 13, fol. 199 . Digital image courtesy of the Getty's Open Content Program.

Catherine is not depicted as actually singing, in reading the prayers in her book she is singing in her heart-indeed, it is partly through her silent song that her devotion achieves its exemplary quality. In this respect, the musical scroll is aligned closely with the statuette of the Virgin and Child placed in the niche above Saint Catherine's lectern. Both are central components of the meditative 
equipment pertaining to exemplary devotion in fifteenth-century Italy. Although Saint Catherine's visual attention is focused upon the book, the statuette (not currently subject to her corporeal vision) nonetheless addresses her inner sight, just as the music addresses her inner hearing, and both serve to elevate her pious contemplation from things earthly to things divine.

The spiritual rewards accrued to those who succeed in elevating their minds and spirits by singing in their hearts are indicated in another miniature from the suffrages, the only other to be accompanied by the Este device of the anchor: that of Saint Mary Magdalene (fig. 5). The Magdalene-whom, like Catherine, the Legenda aurea identifies as a noblewoman-is depicted as a naked hermit, borne aloft on a radiant red disc supported by angels up from a mountainous landscape toward a golden radiance in the sky. ${ }^{91}$ She stands with her hands in an attitude of prayer, her eyes gazing up, her lips parted. This image depicts a specific episode in the Magdalene's story, told in the Legenda aurea. After journeying to Marseilles and converting the city to Christ, the Magdalene withdrew to the wilderness for thirty years. During that period, "Every day at the seven canonical hours she was carried aloft by angels and with her bodily ears heard the glorious chants of the celestial hosts." ${ }^{.92}$ This story, like the similar auditory visions accorded to Caterina Vigri, discussed above, dramatizes the widely reported notion that sacred song, echoing the song of the angels, draws the earthly mind and the soul upwards toward the divine, and at the same time draws the angelic choir down from heaven to augment earthly praises. Mary Magdalene's private celebration of the hours-precisely the devotional activity facilitated by a book of hours-was so exemplary that she, uniquely among mortals, was allowed to participate bodily, seven times a day, for thirty years, in the celestial liturgy. In this episode the Magdalene enjoys bodily the spiritual outcome of singing in the heart, her experience emblematizing the divide, but also the porosity, between audible and silent song, between corporeal and spiritual song, and between earthly and divine song.

These three musical openings clearly reflect the roles assigned to music in contemporary devotional practice, but they do more than reflect: they also instruct the reader by means of inference and exemplification. The matins opening reminds the reader that all earthly praise should emulate the celestial liturgy

\footnotetext{
${ }^{91}$ Voragine, 2012, 375 (Legenda aurea 96.1, “De sancta Maria Magdalena”); Voragine, $1850,408$.

${ }^{92}$ Voragine, 2012, 380 (Legenda aurea 96.2, "De sancta Maria Magdalena"); Voragine, 1850, 413: "Qualibet autem die septem horis canonicis ab angelis in aethera elevabatur et coelestium agminum glosiosos concentus etiam corporalibus auribus audiebat." In view of the presence of angelic song in the episode depicted, it is quite possible that the two blank scrolls winding around white lilies in the margins on either side of this miniature were intended to bear musical notation, like those on the other openings discussed in this study. On Mary Magdalene and music, see Slim; Tammen, 75-77; Jolly, 153-78.
} 


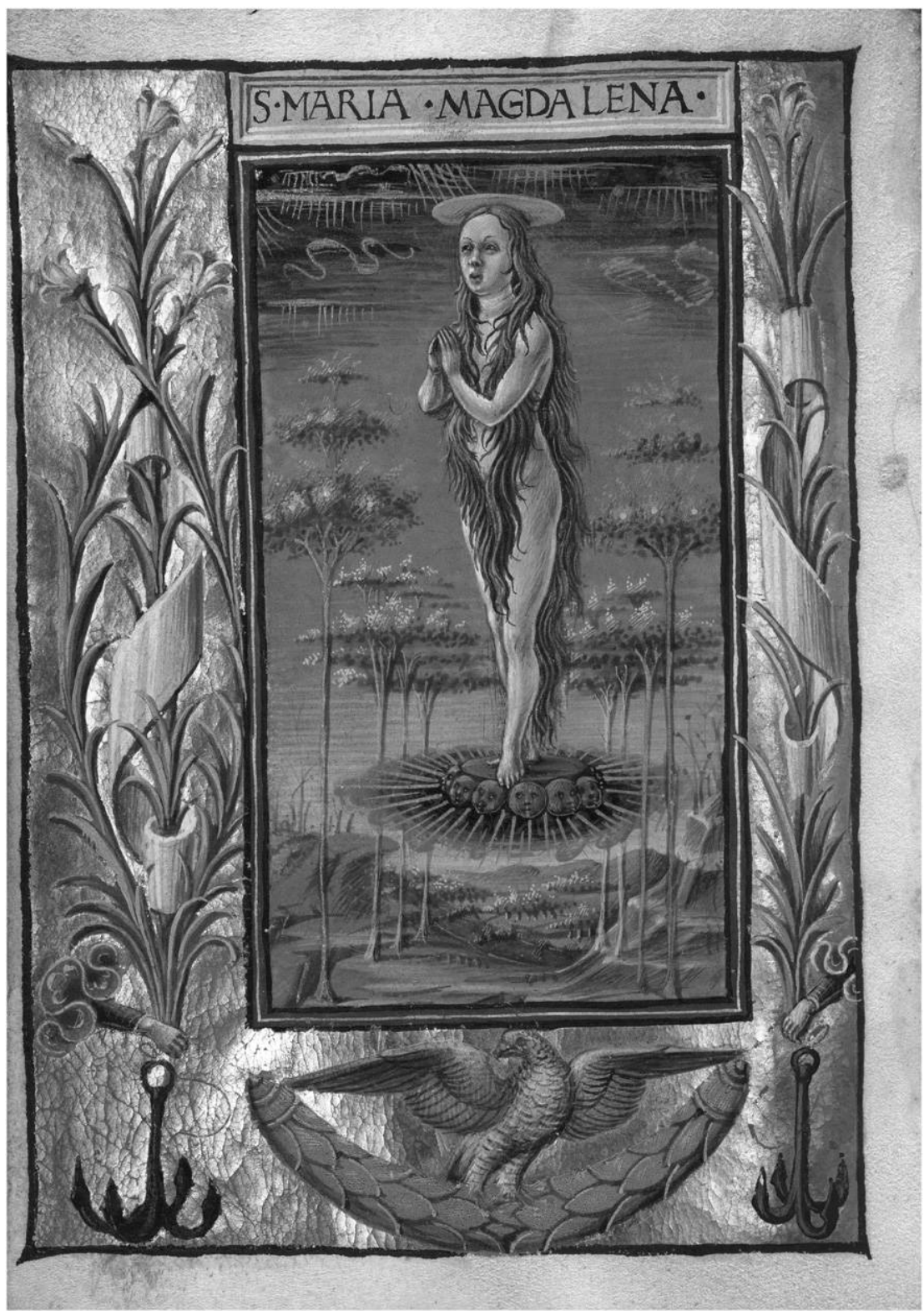

Figure 5. Taddeo Crivelli. Saint Mary Magdalene, ca. 1469. J. Paul Getty Museum, MS Ludwig IX 13, fol. 190 . Digital image courtesy of the Getty's Open Content Program.

celebrated by singing angels and that the psalm they are about to recite is a song. However, it does not require the reader to utter a melody; rather, it prompts them to sing in the heart, a practice that will draw them closer to the divine. The Saint Catherine page presents an example of good devotional practice in which reference 
is made to the roles of both sight and sound; but again, the address is not to the bodily senses but to the inner eye and the inner ear-Saint Catherine is not physically looking at the statuette of the Virgin and Child, and nor is she physically singing. The miniature of Mary Magdalene depicts a well-known scene from her legend in which she experiences an auditory vision that dramatizes the desirable spiritual outcomes resulting from good devotional practice - that is, from singing in the heart. In the latter two cases, the message appears to be aimed at Orsina in particular, through the use of the anchor device referring to her natal family. The central role of music in contemporary devotional practice is here amply demonstrated, but the nature of the music making to which this book refers is perhaps surprising. Far from advocating audible sacred singing — something that the whole corpus of books of hours, in the most part lacking music notation and addressing a very broad readership, would not reliably support—-these images and texts remind the reader to conceive of devotional texts as song and to sing them silently in their hearts, even while reciting them as speech. By adopting this practice, readers would achieve all the substantial spiritual benefits arising from the act of framing sacred texts with music, as described by Augustine and many others, even though not a single musical note is uttered.

\section{FROM SONG TO SILENCE AND BACK}

As the liturgical texts found on the matins opening imply, the inaudibility of the songs found in a book of hours was in many cases only a temporary state. The Angelic Salutation "Ave Maria gratia plena," the text from Psalm 50, and also the implied text of Mary's devotional prayer, the Magnificat, were all liturgical chants, sounding songs performed regularly in church. The "Ave Maria" and the Magnificat were also sometimes set in polyphony at the time the Gualenghid'Este Hours was copied, partly as a result of their popularity in devotional contexts such as books of hours; and although Psalm 50 was not commonly set in polyphony until early in the following century, a three-voice, double-choir Ferrarese setting survives from the 1470s. ${ }^{93}$ These texts were sounding songs in origin and in destination, and their musical connection with liturgy extends the capacity of a book of hours to both reflect and recall their readers' liturgical

\footnotetext{
${ }^{93}$ Contemporary settings of the Angelic Salutation have been reviewed earlier in this essay. Contemporary settings of the Magnificat are surveyed in Lerner. The Ferrarese setting of Psalm 50, "Miserere mei deus," indicated for lauds in Holy Week, is by Ercole d'Este's chapelmaster Johannes Martini and is preserved in Modena, Biblioteca Estense, MS $\alpha . M .1 .11-12$ (on the dating of which see Lockwood, 219-24, 250-57). The close relationship between the popularity of devotional texts in books of hours and their appearance in the motet repertory is one of the central points of Brown.
} 
experience, "a devotional object . . that knit together the liturgy with the everyday life of prayer."

The musical connection extends to many of the texts appearing in a book of hours, a large proportion of which were borrowed from the liturgy, and the popularity of which as devotional texts resulted in some cases in their setting as polyphonic motets. The link between the identity of texts as liturgical chants and their reuse in private devotion as silent songs is nowhere made more explicit than in the Saint Gregory miniature in the suffrages section of the Gualenghi-d'Este Hours (fig. 6). As with the matins opening, some of the texts (fig. 7) associated with this miniature were borrowed from liturgy and circulated as plainchant. The antiphon "O Doctor optime ecclesie," familiar from many books of hours, could be used during vespers on the feast of any saint considered to be a doctor of the Church (principally, of course, Augustine, Jerome, Ambrose, and Gregory). A three-voice motet setting of this text formed part of the repertoire of the choir of St. Peter's basilica in Rome at the time the Gualenghi-d'Este Hours was created. ${ }^{95}$ The ensuing responsory, "Elegit te dominus sacerdotem sibi ad sacrificandum ei hostiam laudis," "96 equally common in books of hours, is modeled partly on Psalm 115:8 ("tibi sacrificabo hostiam laudis et in nomine Domini invocabo"; Vulgata numbering)—itself of course a song - and could be used at matins on a number of different feasts, principal among them the Feast of Peter's Chair (Cathedra Petri, January 18) and the feast of any papal confessor saint. ${ }^{97}$

Alongside these liturgical chants, on the facing page, is a miniature that, highly unusually, appears to show Pope Gregory I as the author of so-called Gregorian chant, singing under the influence of divine inspiration (fig. 6). In the main panel, a pope kneels in prayer before an altar, his lips parted apparently in

\footnotetext{
${ }^{94}$ Reinburg, 6-7, 19-20, 111, 167 (quotation); also Saenger, 149. Even though Reinburg frequently calls attention to the link between books of hours and liturgy, and indeed discusses prayer as a "rite" (Reinberg, 162-71), she makes no reference to the fact that liturgical rites were often, in whole or in part, performed musically. As Baroffio has shown, not only are books of hours valuable sources for the study of liturgical texts, some even transmit their liturgical texts with musical notation: Baroffio, 56, 63-69. We should note with ibid., 45, however, that the liturgical texts reused in books of hours were sometimes altered in ways that would render them incompatible with their chant melodies.

${ }^{95}$ This anonymous motet is preserved in the manuscript Rome, Biblioteca Apostolica Vaticana, MS S. Pietro B.80, which according to Christopher Reynolds was copied for St. Peter's in 1474-75; the motet "O Doctor optime" appears in a layer of the manuscript that was probably copied from an earlier source made for the same institution in 1463. See Reynolds.

96"The Lord has chosen you to be his priest, to offer unto him the sacrifice of praise."

${ }^{97}$ Psalm 115:8 is Psalm 116:17 in the ESV: "I will offer to you the sacrifice of thanksgiving and call on the name of the Lord."
} 


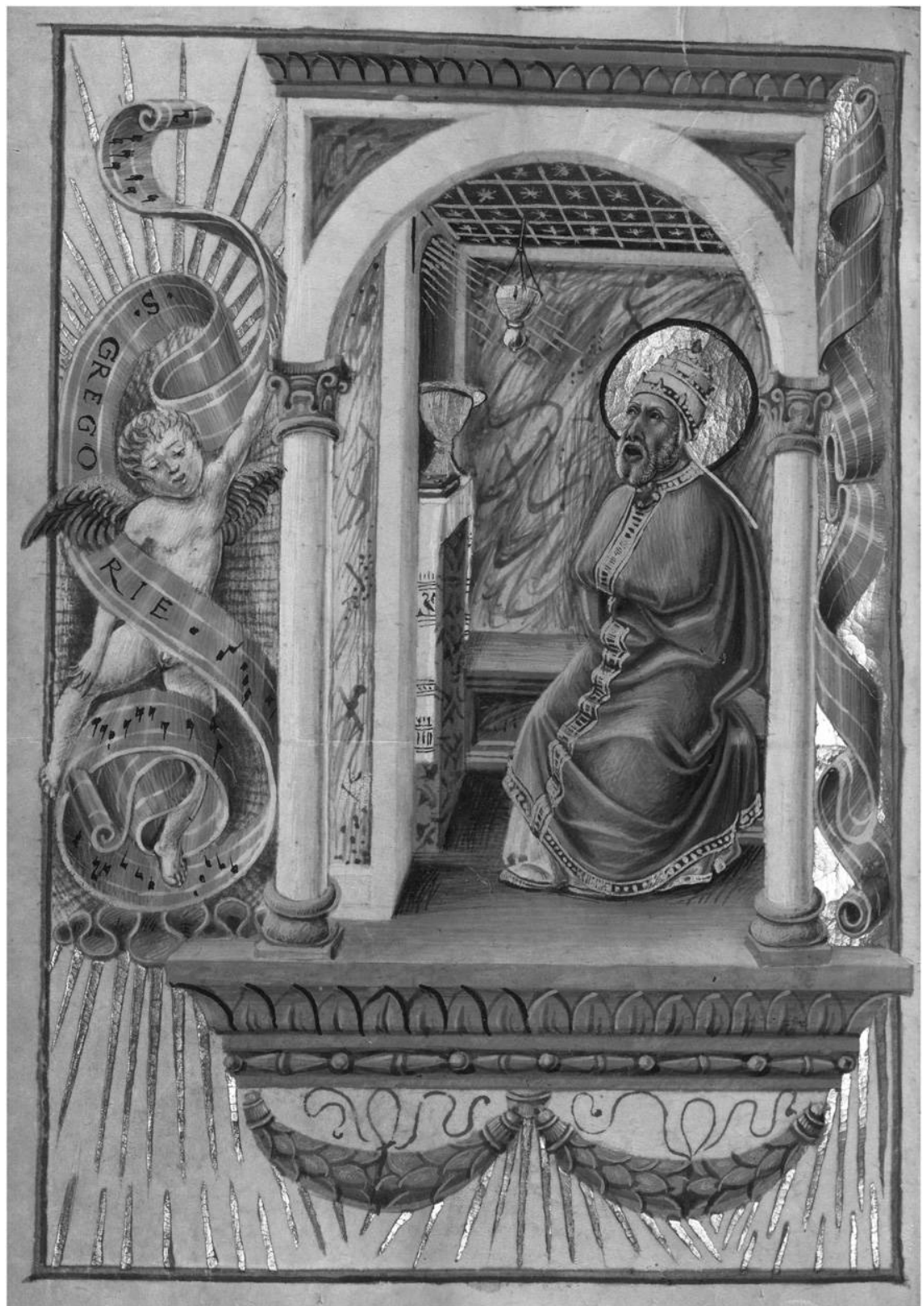

Figure 6. Taddeo Crivelli. Saint Gregory the Great, ca. 1469. J. Paul Getty Museum, MS Ludwig IX 13, fol. $172^{\mathrm{v}}$. Digital image courtesy of the Getty's Open Content Program.

song and his gaze lifted to the heavens whence emanates a golden radiance. In the lefthand margin, an angel bursts forth in a blaze of heavenly light on a blue cloud, bearing a swirling scroll of music on which is inscribed "S. GREGORIE." 


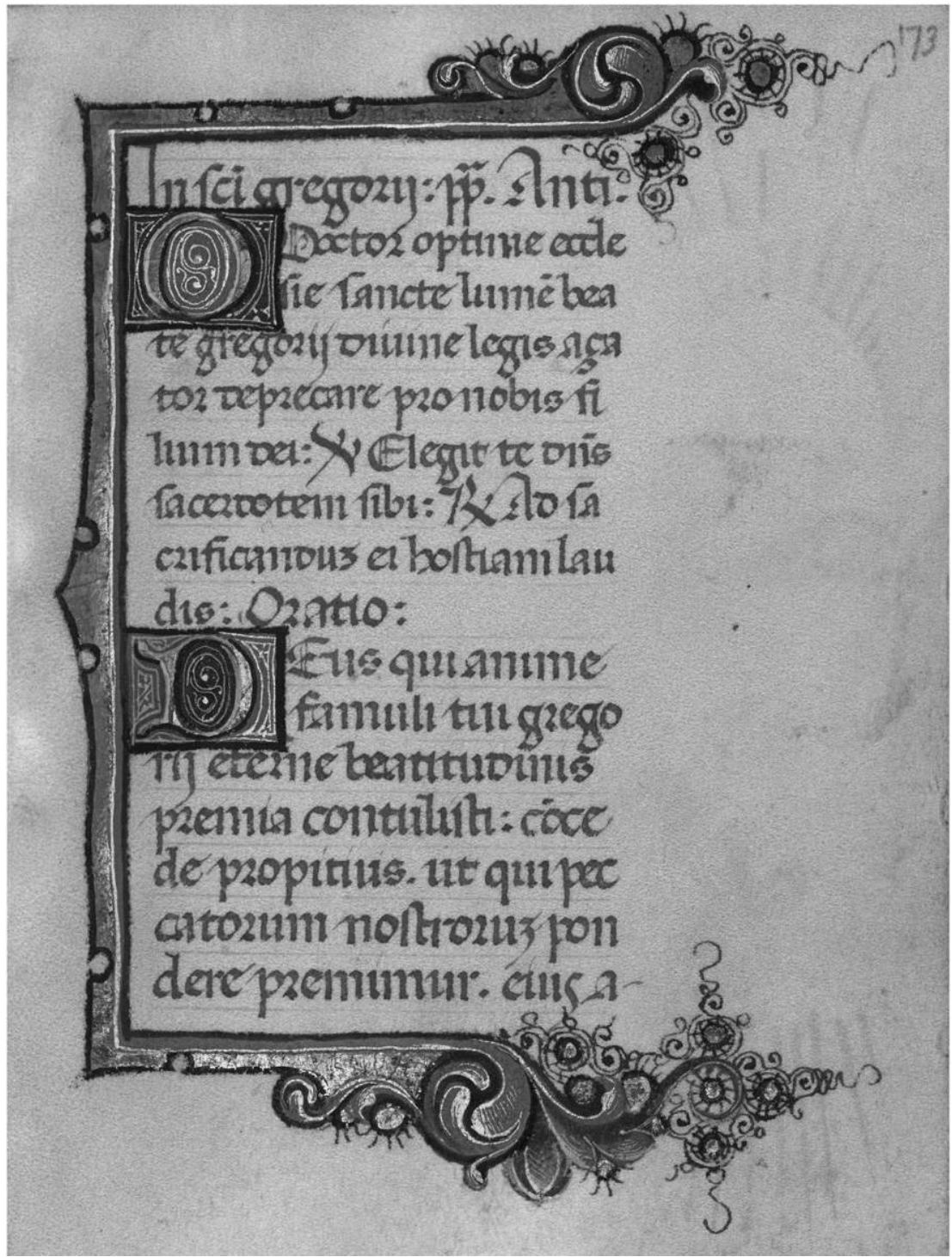

Figure 7. Text to the suffrage for Saint Gregory the Great. J. Paul Getty Museum, MS Ludwig IX 13, fol. $173^{\mathrm{r}}$. Digital image courtesy of the Getty's Open Content Program.

The pope's name is a curious addition here. Some other saint miniatures in the suffrages section of this manuscript bear inscriptions at their head; this is the only case in which an inscription appears at the side, and the only case in which the inscription shares space with other written elements. Presented on the same 
scroll as the neumatic notation, it is suggestive of a composer ascriptionsomething largely alien to the tradition of notated plainchant, but clearly appropriate in this special case, serving to identify Saint Gregory as the author of the Church's chant repertory. The angel bursts forth with this sacred song as if dramatizing the notion of the angels descending to join in with earthly singers. His golden rays are echoed in the rays reaching down toward Saint Gregory in the miniature. In light of what we have earlier established about the capacity of earthly music to prompt mystical experiences, and especially auditory visions in which the inner ear is allowed access to angelic song, it is possible to hypothesize the musical nature of the Saint Gregory scene. It would appear that as the pope sings in prayer, his corporeal experience of sacred song elevates his spirit such that his inner sensorium briefly accesses the celestial liturgy; at the same time, the angelic choirs are drawn by his pious song to lend their voices to his. The scene implies that Gregory's supposed authorship of chant arose as an imitation of the angelic song he encountered through mystical experience.

Perhaps oddly, Gregory's authorship of plainchant was not often taken up within the iconographical traditions surrounding the saint. ${ }^{98}$ Although plainchant was a late addition to Gregory's hagiography (both the link with chant and the term carmen Gregorianum appear after the mid-ninth century), ${ }^{99}$ it was reported in the Legenda aurea and was certainly well known in fifteenthcentury Italy. Voragine informs us that "Gregory remodelled the Church's offices and chant, and founded a school for the chanters, for which he built two houses, one next to Saint Peter's basilica, the other near the Lateran church." 100 Gregory's biography in the Legenda aurea also describes just the sort of auditory vision depicted in the Gualenghi-d'Este Hours: during a procession for penance organized in Rome by Gregory, an image of the Virgin Mary said to be painted by Saint Luke was carried and "the voices of angels were heard around the image, singing 'Regina coeli laetere, alleluia, / Quia quem meruisti portare, alleluia / Resurrexit sicut dixit, alleluia!' ['Queen of heaven rejoice, alleluia; / He whom you were worthy to bear, alleluia; / Has arisen, as he said, alleluia! We ask you to pray for us to God, alleluia!'] to which Gregory added 'Ora pro nobis, Deum

${ }^{98}$ Earlier representations of Gregory as the author of plainchant include Sankt Gallen, Stiftsbibliothek MS 390-1, p. 13 (tenth century); but this presents a quite different iconography_clearly derived from the dictation scene described later in this essay-in which Gregory dictates to an assistant who writes neumes.

${ }^{99}$ The first biography to mention Gregory's connection with chant is that of John the Deacon composed around 873: see Gregory, 1862, 41-60. The first known use of the phrase carmen Gregorianum appears in the correspondence of Pope Leo IV (r. 847-55); see Wyatt, 14.

${ }^{100}$ Voragine, 2012, 180 (Legenda aurea 46.15, “De sancto Gregorio”); Voragine, 1850, 199 : "Officium et cantum ecclesiasticum nec non et scholam cantorum instituit et pro hoc duo habitacula, unum juxta basilicam Petri, alterum juxta Lateranensem ecclesiam fabricavit.” 
rogamus, alleluia!' ['We ask you to pray for us to God, alleluia!']."101 Although rare within visual art, then, the scene depicted in the Gualenghi-d'Este Hours arises quite naturally from the most popular account of the saint's life.

Gregory was more usually represented in two scenes unrelated to his supposed authorship of chant. First, he was frequently associated with a dove and portrayed with this bird whispering into his ear. Early biographers report that Peter, Gregory's deacon and scribe, recounted having seen the Holy Spirit in the likeness of a dove over the pope's head, dictating the Homiliae in Ezechielem. ${ }^{102}$ This anecdote was very popular, and the episode was often depicted in visual art. Alternatively, artists reached for the story of the so-called Mass of Saint Gregory. Voragine reports that once, when Gregory was celebrating Mass, a woman could not believe that the Host was the body of Jesus Christ, as she herself had baked the bread beforehand. Gregory prayed, and the bread changed into a finger; he prayed again, and the finger returned to bread. The woman was convinced. ${ }^{103}$ The overwhelming prevalence of these two episodes in visual representations of Saint Gregory make the choice of a musical scene in the Gualenghi-d'Este Hours all the more pointed: it was not at all the obvious option, and so may have carried particular significance for one of those involved in the book's production and for its owners Andrea and Orsina.

By depicting the very moment at which divine inspiration prompted Saint Gregory to create liturgical chant, the Saint Gregory opening reminds the reader that all earthly sacred song is in conception a faint echo of the celestial liturgy sung by angels, an auditory translation of a musical practice that normally exists beyond the bodily sense of hearing. Saint Gregory-like Mary Magdalene and Caterina Vigri-is depicted in an act that emblematizes the relationship between earthly and heavenly song: he is singing, and through the spiritual efficacy of song he is drawn closer to the divine. At the same time, it is his encounter with the divine and with the celestial liturgy that inspires him to sing. The Saint Gregory opening holds out to the reader the possibility of emulating the pope's spiritual achievement by singing-silently, in the heart-the Gregorian liturgical chants given on the facing page. At the same time, it reminds the reader of the theological rationale lying behind the sounding song of the church by depicting the supposed manner of its instigation at the hands of Pope Gregory

${ }^{101}$ Voragine, 2012, 173-74 (Legenda aurea 46.4, "De sancto Gregorio"); Voragine, 1850, 192: "Tunc in aere, ut refertur, juxta imaginem auditae sunt voces angelorum cantantium: 'Regina coeli laetere, alleluia, Quia quem meruisti portare, alleluia. Resurrexit sicut dixit, alleluia.' Statimque beatus Gregorius, quod sequitur, adjunxit 'Ora pro nobis, Deum rogamus, alleluia."”

${ }^{102}$ Colgrave, 120 (Liber beati et laudabilis viri Gregorii 26); Voragine, 2012, 181 (Legenda aurea 46.16, "De sancto Gregorio"); Wyatt, 38.

${ }^{103}$ Voragine, 2012, 179-80 (Legenda aurea 46.11, "De sancto Gregorio"). 
I, and by drawing their attention both to the audible origins of the liturgical songs that make up much of the text of a book of hours and also to the audible destination of some such texts in the form of polyphonic motets.

\section{CONCLUSIONS}

In this study we have found certain images and texts in the Gualenghi-d'Este Hours to engage closely with the well-documented roles of music within contemporary devotional practice. This manuscript identifies music, and specifically plainchant, both as emerging from the angelic song of the celestial liturgy and also as a means by which the devotee might, in response, reach back toward the divine. Reference is made, directly (in the case of Mary Magdalene) and indirectly, to both the distinction and the permeability between the bodily audibility of human song and the bodily inaudibility of divine song. The manuscript prompts the reader to engage the spiritual effects imputed to music by singing its texts in the heart, inaudibly rather than audibly, at the same time reminding the reader of their nature as, in many cases, borrowings from audible biblical and liturgical songs. Such a devotional performance might coincide with a sounding performance of the texts as song-and the lack of functional musical notation is no great hindrance to that within contemporary oral musical practice-but it might equally be contained entirely within the inner sensorium. The widely reported power of music to enhance pious experience could be engaged either way.

This analysis has significant broader implications for our understanding of music, devotional texts, and devotional practices in the period. These musical inflections of the lay devotional practice of reciting the canonical hours are rendered particularly explicit in this book of hours, more so than in many other devotional books, but they align so closely with the general view of music's role in devotion, gleaned from a wider range of sources, that we can assume them to be a normal aspect of lay devotion in fifteenth-century Italy. Music's role is described by this source not primarily as that of a sounding art, but as an imaginative practice and as a metaphor for a particular quality of engagement with religious texts - one that enables the devotee to comprehend more fully and more profoundly their valence. This silent music is identified, with some theological justification, as fulfilling its task of echoing the song of angels just as successfully as, and perhaps more successfully than, sounding song. In light of this, it may be that music enjoyed as much or greater purchase and significance as a way of conceiving of religious texts in the period than it did as a way of hearing them. As a repository of texts for devotional performance, a book of hours is revealed by this analysis to be a document engaged in the musicality of devotional practice, even though not a single note of functional music appears within it. 


\section{BIBLIOGRAPHY}

Alden, Jane. Songs, Scribes and Society: The History and Reception of the Loire Valley Chansonniers. Oxford: Oxford University Press, 2010.

Arienti, Giovanni Sabadino degli. Gynevera de le Clare donne. Charleston: Nabu, 2010.

Aristotle. On the Soul; Parva naturalia; On Breath. Trans. W. S. Hett. London: Heinemann, 1935.

Augustine of Hippo. Opera Omnia. Vol. 33 of Patrologia Latina. Ed. J.-P. Migne. Paris, 1841a.

- Opera Omnia. Vol. 34 of Patrologia Latina. Ed. J.-P. Migne. Paris, 1841 b.

Lectures or Tractates on the Gospel According to St. John. Trans. John Gibb and James

Innes. Vol. 7 of A Select Library of the Nicene and Post-Nicene Fathers of the Christian Church. Edinburgh: T. and T. Clark, 1873.

- The Confessions and Letters of St. Augustin, with a Sketch of his Life and Work. Trans. J. G. Pilkington and J. G. Cunningham. Vol. 1 of A Select Library of the Nicene and PostNicene Fathers of the Christian Church. Buffalo: Christian Literature, 1886.

-. In Johannis Evangelium tractatus cxxiv. Ed. Radbodus Willems. Vol. 36.8 of Corpus Christianorum Series Latina. Turnholt: Brepols, 1954.

. Confessionum libri XIII. Ed. Lucas Verheijen. Vol. 27 of Corpus Christianorum Series Latina. Turnholt: Brepols, 1981.

. On Genesis: A Refutation of the Manichees, Unfinished Literal Commentary on Genesis, the Literal Meaning of Genesis. Trans. Edmund Hill. Ed. John E. Rotelle. Vol. 1.13 of The Works of Saint Augustine: A Translation for the 21st Century. Brooklyn: New City Press, 1990.

Baroffio, Bonifacio. "Testo e musica nei libri d'ore." Rivista italiana di musicologia 46 (2011): $18-77$.

Barstow, Kurt. The Gualenghi-d'Este Hours: Art and Devotion in Renaissance Ferrara. Los Angeles: J. Paul Getty Museum, 2000.

Beleth, Johannes. Summa de Ecclesiasticis Officiis. Ed. Herbert Douteil. Vol. 41 of Corpus Christianorum Continuatio Mediaevalis. Turnholt: Brepols, 1976.

Bembo, Illuminata. Specchio di illuminazione. Ed. Silvia Mostaccio. Florence: SISMEL edizioni del Galluzzo, 2001.

Bernstein, Lawrence F. “Ockeghem's Ave Maria: Evidence of Structural Cogency.” In From Ciconia to Sweelinck: Donum Natalicium Willem Elders, ed. Albert Clement and Eric Jas, 75-90. Amsterdam: Rodopi, 1994.

Bertoni, Giulio. "La Biblioteca di Borso d'Este." Atti della Reale Accademia delle Scienze di Torino 61.14 (1926): 379-402.

Biblioteca Estense, Modena, MS Lat. 309 Alpha W.4.4. Ariosti, Francesco. "De novi intra ducalem regio ferrariensem delubri in Gloriosissime Virginis Domini Iesu Christi Salvatoris Nostri Matris ecc." 1472-76.

Biernoff, Suzannah. Sight and Embodiment in the Middle Ages. Basingstoke: Palgrave Macmillan, 2002.

Blackburn, Bonnie. "For Whom Do the Singers Sing?” Early Music 25.4 (1997): 593-609. "Messages in Miniature: Pictorial Programme and Theological Implications in the Alamire Choirbooks." In The Burgundian-Habsburg Court Complex of Music Manuscripts (1500-1535) and the Workshop of Petrus Alamire, ed. Bruno Bouckaert and Eugeen Schreurs, 161-84. Leuven: Alamire, 2003. 
Bonaventure, Saint. Meditations on the Life of Christ: An Illustrated Manuscript of the Fourteenth Century, Paris, Bibliothèque Nationale, Ms. Ital. 115. Trans. Isa Ragusa. Princeton: Princeton University Press, 1961.

Brothers, Lester D. "On Music and Meditation in the Renaissance: Contemplative Prayer and Josquin’s Miserere.” Lournal of Musicological Research 12 (1992): 157-87.

Brown, Howard Mayer. "The Mirror of Man's Salvation: Music in Devotional Life about 1500.” Renaissance Ouarterly 43.4 (1990): 744-73.

Burnett, Charles, Michael Fend, and Penelope Gouk, eds. The Second Sense: Studies in Hearing and Musical Judgement from Antiquity to the Seventeenth Century. London: Warburg Institute, 1991.

Camille, Michael. Image on the Edge: The Margins of Medieval Art. London: Reaktion, 1992. - "Before the Gaze: The Internal Senses and Late Medieval Practices of Seeing." In Visuality before and beyond the Renaissance: Seeing as Others Saw, ed. Robert S. Nelson, 197-223. Cambridge: Cambridge University Press, 2000.

Colgrave, Bertram, ed. and trans. The Earliest Life of Gregory the Great by an Anonymous Monk of Whitby. Cambridge: Cambridge University Press, 1985.

Constant, John. "A Book of Hours for Pope Leo X." In Music from the Middle Ages through the Twentieth Century: Essays in Honor of Gwynn S. McPeek, ed. Carmelo P. Comberiati and Matthew C. Steel, 314-34. New York: Gordon and Breach, 1988.

Cullington, J. Donald, and Reinhard Strom, eds. and trans. "That Liberal and Virtuous Art": Three Humanist Treatises on Music. Newtownabbey: University of Ulster, 2001.

Dean, Jeffrey. “Listening to Sacred Polyphony c. 1500.” Earlv Music 25 (1997): 611-36.

—. "The Polyphonic Vesperal Manuscript Type, Du Faÿ's Hymns, and Institutional Identity in the Papal Chapel, 1400-1600." In Sources of Identity: Makers, Owners and Users of Music Sources before 1600, ed. Lisa Colton and Tim Shephard, 133-68. Turnhout: Brepols, 2017.

Delaissé, L. M. J. "The Importance of Books of Hours for the History of the Medieval Book." In Gatherings in Honor of Dorothy E. Miner, ed. Ursula E. McCracken, Lilian M. C. Randall, and Richard H. Randall Jr., 203-26. Baltimore: Walters Art Gallery, 1974.

Deshman, Robert. "Another Look at the Disappearing Christ: Corporeal and Spiritual Vision in Early Medieval Images." Art Bulletin 79.3 (1997): 518-46.

Duffy, Eamon. Marking the Hours: English People and Their Prayers 1240-1570. New Haven: Yale University Press, 2006.

Dumitrescu, Theodor. "Reconstructing and Repositioning Regis's Ave Maria . . virgo serena." Earlv Music 37.1 (2009): 73-88.

Ficino, Marsilio. De Vita Libri Tres. Basel, 1529.

- The Three Books on Life. Trans. Carol V. Kaske and John R. Clark. Binghamton: Medieval and Renaissance Texts and Studies in conjunction with the Renaissance Society of America, 1989.

Filippi, Daniele V. "Selva Armonica": La musica spirituale a Roma tra Cinque e Seicento. Turnhout: Brepols, 2008.

Gafori, Franchino. Practica Musice. Milan, 1496. In Thesaurus Musicarum Latinarum, dir. Giuliano di Bacco: http://boethius.music.indiana.edu/tml/15th/GAFPM1.

- The Practica Musicae of Franchinus Gafurius. Trans. Irwin Young. Madison: University of Wisconsin Press, 1969. 
The Theory of Music. Trans. Walter Kurt Kreyszig. Ed. Claude V. Palisca. New Haven:

Yale University Press, 1993.

- Theorica Musice. Ed. Ilde Illuminati. Florence: Edizioni del Galluzzo, 2005.

Galen. On the Usefulness of the Parts of the Body: De Usu Partium. Trans. Margaret Tallmadge May. 2 vols. Ithaca: Cornell University Press, 1968.

Gill, Meredith. Angels and the Order of Heaven in Medieval and Renaissance Italy. Cambridge: Cambridge University Press, 2014.

Gregory, Saint. Opera Omnia. Vol. 75 of Patrologia Latina. Ed. J.-P. Migne. Paris, 1862.

—. Registrum Epistularum Libri VIII-XIV, Appendix. Ed. Dag Norberg. Vol. 140a of Corpus Christianorum Series Latina. Turnholt: Brepols, 1982.

—. Homélies sur Ézéchiel. Ed. and trans. Charles Morel. 2 vols. Paris: Cerf, 1986.

Harthan, John. Books of Hours and Their Owners. London: Thames and Hudson, 1977.

Hindman, Sandra, and James H. Marrow, eds. Books of Hours Reconsidered. London: Harvey Miller, 2013.

Huck, Oliver. "The Music of the Angels in Fourteenth- and Early Fifteenth-Century Music." Musica Disciplina 53 (2003-08): 99-119.

Iversen, Gunilla. Chanter avec les anges: Poésie dans la messe médiévale: Interprétations et commentaires. Paris: Cerf, 2001.

Jager, Eric. "The Book of the Heart: Reading and Writing the Medieval Subject." Speculum 71 (1996): 1-26.

Jerome, Saint. Opera Omnia. Vol. 22 of Patrologia Latina. Ed. J.-P. Migne. Paris: Garnier, 1845. . Opera Omnia. Vol. 26 of Patrologia Latina. Ed. J.-P. Migne. Paris: Garnier, 1859.

- Letters and Select Works. Ed. and trans. Philip Schaff and Henry Wace. Vol. 6 of $A$

Select Library of the Nicene and Post-Nicene Fathers of the Christian Church. New York: Christian Literature, 1893.

Johannis de Caulibus. Meditaciones Vite Christi. Ed. M. Stallings-Taney. Vol. 153 of Corpus Christianorum Continuatio Mediaevalis. Turnholt: Brepols, 1997.

John Chrysostom, Saint. Opera Omnia. Vol. 56 of Patrologia Graeca. Ed. J.-P. Migne. Paris, 1862. Jolly, Penny Howell. Picturing the "Pregnant" Magdalene in Northern Art, 1430-1550: Addressing and Undressing the Sinner-Saint. Farnham: Ashgate, 2014.

Jütte, Robert. A History of the Senses: From Antiquity to Cyberspace. Cambridge: Polity, 2005.

Kessler, Herbert L. Spiritual Seeing: Picturing God's Invisibility in Medieval Art. Philadelphia: University of Pennsylvania Press, 2000.

Lerner, E. R. "The Polyphonic Magnificat in 15th-Century Italy." Musical Quarterly 1 (1964): 44-58.

Lockwood, Lewis. Music in Renaissance Ferrara, 1400-1505. Oxford: Oxford University Press, 1984.

Macey, Patrick. “Josquin's 'Little' 'Ave Maria': A Misplaced Motet from the 'Vultum tuum' Cycle?” Tiidschrift van de Verenioing voor Nederlandse Muziekoeschiedenis 39 (1989): 38-53.

- Bonfire Songs: Savonarola's Musical Legacy. Oxford: Clarendon Press, 1998.

Maggioni, Giovanni Paolo. "Le molte Legende Auree: Modificazioni testuali e itinerari narrativi." In De la sainteté à l'hagiographie: Genèse et usage de la "Légende dorée," ed. Barbara Fleith and Franco Morenzoni, 15-39. Genève: Droz, 2001.

McKinnon, James. Music in Early Christian Literature. Cambridge: Cambridge University Press, 1989. 
Meconi, Honey. "A Cultural Theory of the Chansonnier." In Uno gentile et subtile ingenio (2009), 649-57.

Mondino dei Liuzzi. Anothomia. Ed. and trans. Piero Giorgi. http://cis.alma.unibo.it/ Mondino/lat_ita.html.

Nelson, Robert, ed. Visuality before and beyond the Renaissance: Seeing as Others Saw. Cambridge: Cambridge University Press, 2000.

Nichols, Stephen G., Andreas Kablitz, and Alison Calhoun, eds. Rethinking the Medieval Senses: Heritage, Fascinations, Frames. Baltimore: John Hopkins University Press, 2008.

Nordenfalk, Carl. "The Five Senses in Medieval and Renaissance Art." Journal of the Warburg and Courtald Institutes 48 (1985): 1-22.

Owens, Jessie Ann. "'And the angel said . . . ': Conversations with Angels in Early Modern Music." In Conversations with Anoels: Essavs Towards a History of Stiritual Communication. 1100-1700, ed. Joad Ravmond, 230-49. Basingstoke: Palgrave Macmillan, 2011.

Owens, Margareth Boyer. "Musical Subjects in the Illumination of Books of Hours from Fifteenth-Century France and Flanders.” PhD diss., University of Chicago, 1987.

Pietschmann, Klaus. "The Sense of Hearing Politicized: Liturgical Polyphony and Political Ambition in Fifteenth-Century Florence." In Religion and the Senses in Early Modern Europe, ed. Wietse de Boer and Christine Gottler, 271-88. Leiden: Brill, 2013.

- "Religion and the Senses in Fifteenth-Century Europe." In The Cambridge History of Fifteenth-Century Music, ed. Anna Maria Busse Berger and Jesse Rodin, 40-51. Cambridge: Cambridge University Press, 2015.

Quiviger, François. “Seeing and Looking in the Renaissance.” In La Vista y la Visión, ed. Pedro Azara, 68-81. Valencia: IVAM, 2003.

- The Sensory World of Italian Renaissance Art. London: Reaktion, 2010.

Reames, Sherry L. The "Legenda aurea": A Reexamination of Its Paradoxical History. Madison: University of Wisconsin Press, 1985.

Reinburg, Virginia. French Books of Hours: Makino an Archive of Praver, ca. 1400-1600. Cambridge: Cambridge University Press, 2012.

Reynolds, Christopher. "The Origins of San Pietro B 80 and the Development of a Roman Sacred Repertory.” Earlv Music History 1 (1981): 257-304.

Rifkin, Joshua. "Munich, Milan, and a Marian Motet: Dating Josquin’s Ave Maria . . virgo serena." Iournal of the American Musicological Society 56.2 (2003): 239-50.

Ringbom, Sixten. Icon to Narrative: The Rise of the Dramatic Close-Up in Fifteenth-Century Devotional Painting. Doornspijk: Davaco, 1984.

Rudy, Gordon. Mystical Language of Sensation in the Later Middle Ages. New York: Routledge, 2002.

Saenger, Paul. "Books of Hours and the Reading Habits of the Later Middle Ages." In The Culture of Print, trans. Lydia Cochrane, ed. Roger Chartier, 141-73. Princeton: Princeton University Press, 1989.

Sandler, Lucy F. "The Study of Marginal Imagery: Past, Present and Future." Studies in Iconography 18 (1997): 1-49.

Savonarola, Girolamo. Triumphus crucis: Testo latino e volgare. Ed. Mario Ferrara. Rome: Belardetti, 1961.

Schutte, Anne Jacobson. Printed Italian Vernacular Religious Books 1465-1550: A Finding List. Geneva: Droz, 1983. 
Slim, H. Colin. "Mary Magdalen, Musician and Dancer." Earlv Music 8 (1980): 460-73.

Spano, Serena. "Per uno studio su Caterina da Bologna." Studi medievali, 3rd ser., 12.2 (1971): 713-59.

Steinberg, Ronald M. Fra Girolamo Savonarola, Florentine Art, and Renaissance Historiography. Athens: Ohio University Press, 1977.

Stocks, Bronwyn. "Devotional Emphasis and Distinctive Variation in the Illustration of the Hours of the Virgin in Italian Books of Hours." In Books of Hours Reconsidered, ed. Sandra Hindman and James H. Marrow, 365-87. London: Harvey Miller, 2013.

Tammen, Björn. "Prayers and Beyond: The Musical 'Image on the Edge' in Fifteenth-Century Books of Hours." In Prospettive di iconografia musicale, ed. Nicoletta Guidobaldi, 71-108. Milan: Mimesis, 2007.

Tinctoris, Johannes. De Inventione et Usu Musice. Ed. and trans. Jeffrey Dean. http:// earlymusictheory.org/Tinctoris/texts/deinventioneetusumusice.

Toniolo, Federica, ed. La Miniatura a Ferrara: Dal tempo di Cosmè Tura all'eredità di Ercole de' Roberti. Modena: Franco Cosimo Panini, 1998.

Uno gentile et subtile ingenio: Studies in Renaissance Music in Honour of Bonnie J. Blackburn. Ed. Jennifer M. Bloxam, Gioia Filocamo, and Leofranc Holford-Strevens. Turnhout: Brepols, 2009.

Vigri, Caterina. Le sette armi spirituali. Ed. Antonella Degl'Innocenti. Firenze: SISMEL edizioni del Galluzzo, 2000.

Vinge, Louise. The Five Senses: Studies in a Literary Tradition. Lund: Gleerup, 1975.

Voragine, Jacobus de. Legenda aurea. Ed. Johann Grässe. 2nd ed. Leipzig: Librariae Arnoldianae, 1850.

- The Golden Legend: Readings on the Saints. Trans. William Granger Ryan. Princeton: Princeton University Press, 2012.

Ward, Tom R. “The Structure of the Manuscript Trent 92-I.” Musica Disciplina 29 (1975): $127-47$.

Wegman, Rob C. The Crisis of Music in Early Modern Europe, 1470-1530. New York: Routledge, 2005.

- "Tinctoris's Magnum opus." In Uno gentile et subtile ingenio (2009), 771-82.

Wieck, Roger S. Painted Prayers: The Book of Hours in Medieval and Renaissance Art. New York: George Braziller, 1997.

- Time Sanctified: The Book of Hours in Medieval Art and Life. 2nd ed. New York: George Braziller, 2001.

Williamson, Beth. "Sensory Experience in Medieval Devotion: Sound and Vision, Invisibility and Silence." Speculum 88.1 (2013): 1-43.

Wright, Peter. "The Compilation of Trent 87, and 92." Earlv Music History 2 (1982): 237-71.

—. "On the Origins of Trent 87 1 and 92." Earlv Music History 6 (1986): 245-70.

. "Paper Evidence and the Dating of Trent 91." Music and Letters 76.4 (1995): 487-508.

—. "Johannes Wiser's Paper and the Copying of His Manuscripts." In I codici musicali trentini: Nuove scoperte e nuovi orientamenti della ricerca, ed. Peter Wright, 31-53. Trent: Provincia autonoma di Trento, 1996.

Wyatt, E. G. P. St. Gregory and the Gregorian Music. London: Plainsong and Mediaeval Music Society, 1904. 